Hispania Sacra, LXII

126, julio-diciembre 2010, 563-619, ISSN: 0018-215-X

\title{
LOS MIEMBROS DEL CABILDO DE LA CATEDRAL DE TOLEDO DURANTE EL ARZOBISPADO DE GASPAR DE QUIROGA
}

$$
(1577-1594)^{*}
$$

\author{
POR \\ Henar Pizarro Llorente \\ Universidad Pontificia Comillas
}

\section{RESUMEN}

Gaspar de Quiroga fue nombrado arzobispo de Toledo tras la muerte de Bartolomé de Carranza. Su avanzada edad le convertía en un buen candidato ante Felipe II, que preparaba su sucesión en el archiduque Alberto de Austria. Durante los años de su prelacía, Quiroga mantuvo unas relaciones cordiales con el cabildo catedralicio, que fueron el resultado de su conocimiento de los asuntos del arzobispado y de la introducción en el consistorio de sus protegidos y familiares.

PALABRAS CLAVE: Gaspar de Quiroga, arzobispado de Toledo, cabildo catedralicio.

\section{THE MEMBERS OF THE CATHEDRAL CHAPTER OF TOLEDO UNDER GASPAR DE QUIROGA ARCHBISHOP (1577-1594)}

\begin{abstract}
Gaspar de Quiroga was named Archbishop of Toledo after the death of Bartolomé de Carranza. Because of his old age, he was a good candidate for Felipe II, who was preparing Archduke Alberto de Austria as the next archbishop. Quiroga had a good relationship with the cathedral chapter in the period of his prelacy due the knowledge he had about the affairs of the archdiocese and the fact that he had been placing their relatives and protégés in the consistory.
\end{abstract}

\footnotetext{
* Este trabajo forma parte del proyecto S2007/HUM-0425, subvencionado por la Comunidad Autónoma de Madrid.
} 
KEY WORDS: Gaspar de Quiroga, archbishop of Toledo, cathedral chapter.

Recibido/Received 21-01-2009

Aceptado/Accepted 27-05-2010

La muerte de Bartolomé de Carranza, en marzo de 1576, propiciaba el nombramiento de un nuevo prelado en la sede toledana. Si bien Felipe II había manifestado de forma reiterada el deseo de que su sobrino, el archiduque Alberto de Austria, ocupase la silla primada, la juventud del pretendiente, unido a las altas rentas que quedarían bajo su administración y los tradicionales inconvenientes que se habían derivado para la Corona de la vinculación de esta dignidad a miembros de significados de la sociedad, llevaron al monarca a cambiar de criterio. Antonio Pérez supo despertar las reticencias del rey e inclinar su ánimo hacia la designación de un hombre que el secretario buscaba atraer de manera definitiva a la facción cortesana que encabezaba. La condición de sexagenario de Gaspar de Quiroga hacía presagiar un pontificado no muy prolongado. De esta manera, en consonancia con los deseos del rey, el archiduque podía finalizar su formación y alcanzar la madurez necesaria para cumplir convenientemente con tan significada labor. ${ }^{1}$ Así pues, el 17 de agosto de 1577, Felipe II informaba al embajador en Roma de la designación de Quiroga como nuevo prelado toledano. Las bulas correspondientes llegaban a la Corte a finales de septiembre, procediéndose a la toma de posesión el 23 de octubre. ${ }^{2}$ Sin duda, el monarca no pudo prever que don Gaspar se mantendría al frente de la sede durante los siguientes diecisiete años. Durante este periodo, las relaciones entre el arzobispo y el cabildo catedralicio fueron cordiales. El buen entendimiento entre ambas instancias se sostuvo sobre dos pilares: el excelente conocimiento que Quiroga tenía del arzobispado toledano y la voluntad del prelado de dominar al consistorio a través de la introducción en el mismo de sus protegidos y familiares.

\section{GASPAR DE QUIROGA Y LA IGLESIA TOLEDANA}

La relación de Gaspar de Quiroga con el arzobispado de Toledo se iniciaba en 1540, cuando su protector, el arzobispo Juan Pardo de Tavera, le proveía vicario general en Alcalá de Henares. ${ }^{3}$ Aunque sin poderes específicos para ello,

\footnotetext{
${ }^{1}$ En relación con estas cuestiones, véase, Baltasar PorreÑo, Dichos y hechos del rey D. Felipe II. Madrid 1942 (Ed. fácsímil), 412-414; Gregorio MARAÑón, Antonio Pérez (el hombre, el drama, la época). Buenos Aires, Espasa-Calpe, 1947, I, 122.

${ }^{2}$ AGS, PR, leg. 42, nº 117; Pedro SalazAR y Mendoza, Crónica del Cardenal don Juan de Tavera. Toledo 1603, 294-295.

${ }^{3}$ Ibidem 82-83; J. Benedict WarRen, Vasco de Quiroga y sus hospitales pueblo en Santa Fe. Universidad de Michoacán 1977, 25.

Hispania Sacra, LXII

126, julio-diciembre 2010, 563-619, ISSN: 0018-215-X
} 
don Gaspar se iniciaba en la realización de labores inquisitoriales, dinamizaba la vida cultural de la ciudad, y establecía sus primeros contactos con los miembros de la Compañía de Jesús. Concretamente, generaba una estrecha amistad con el P. Fabro, que, posteriormente, se hizo extensiva a otros miembros de la orden. Sin duda, la cercanía y vinculación de Quiroga a los jesuitas fue una constante a lo largo de su vida. ${ }^{4}$

El intento del Cardenal Tavera de mantener a la universidad complutense bajo su control tuvo como consecuencia el nombramiento de don Gaspar en el cargo de maestrescuela, que sumaba a su dignidad de vicario, en torno a $1542 . .^{5}$ El enfrentamiento y la impetuosa actitud que mantuvo con un notario pontificio durante la presentación de unas letras apostólicas a favor de la jurisdicción universitaria y en detrimento de las pretensiones del prelado provocaban que fuese requerida por el pontífice la presencia de Quiroga en Roma. Sin embargo, el influjo de Tavera y el respaldo procurado por el príncipe Felipe provocaron que el regalismo y la defensa de los intereses arzobispales exhibidos por el vicario general se viesen premiados con la eximente de tener que acudir a rendir cuentas de su comportamiento ante el papa. El 12 de junio de 1545, pocos días antes de la muerte del Cardenal, don Gaspar tomaba posesión de una canonjía de la catedral toledana. ${ }^{6}$

El fallecimiento de Tavera dejaba a Quiroga huérfano de protección ante los llamamientos de su persona que se realizaban desde Roma. A pesar de que fue proveído vicario general del arzobispado durante la sede vacante, y de que se había ocupado durante algunos meses, junto al resto de los miembros del cabildo, de los problemas de la titularidad del Adelantamiento de Cazorla, don Gaspar no pudo eludir su visita al pontífice cuando se produjo la notificación de su excomunión, que fue realizada al deán de la catedral el 2 de noviembre de 1545 , circunstancia que fue aprovechada por Juan de Segovia para impetrar su canonjía. Durante esta primera estancia en Roma, Quiroga pudo contar con la ayuda y mediación de Ignacio de Loyola ante el papa Paulo III, y conseguir la absolución. ${ }^{7}$

Retornado a Toledo en el verano de 1546, se reincorporaba a las actividades del capítulo catedralicio. El encumbramiento político de Fernando de Valdés, adversario político de Tavera, condicionaba la búsqueda de cobijo por parte de

\footnotetext{
${ }^{4}$ En torno a la misma, véase, Henar PizArro Llorente, Un gran patrón en la Corte de Felipe II. Don Gaspar de Quiroga. Madrid, Universidad Pontificia Comillas 2004.

${ }^{5}$ BCSV, Ms. no 16 , fol. 143r.

${ }^{6}$ ACT, Actas capitulares, tomo 7, fols. 37v-38r.

7 Ibid., fols. 41r, 45r, 110r-111v; Juan Francisco RIVERA Recio, El Adelantamiento de Cazorla. Historia general. Toledo, Católica toledana, 1948, 99-104; Jerónimo Román DE LA HigUERA, Historia eclesiástica de la imperial ciudad de Toledo (BN, Ms. 1293), fols. 179-180.
} 
Quiroga en el entorno toledano. Así, comenzaba a colaborar activamente con el nuevo arzobispo Juan Martínez Silicio. Concretamente, destacaba por su participación en la adopción y aprobación de los Estatutos de limpieza de sangre por parte de la catedral, así como en otras actuaciones de carácter reformístico, como la realización de diversas visitas auspiciadas tanto por el propio cabildo como por parte del prelado, o sus intervenciones en defensa de la jurisdicción y de las rentas de la iglesia toledana frente a otras instancias. No obstante, las divergencias entre Quiroga y Martínez Silicio en materia de religiosidad provocaron que surgiese el enfrentamiento entre ambos. Si bien estas tensiones se desarrollaron en el contexto de los conflictos surgidos entre el arzobispo y el cabildo, fueron coincidentes en el tiempo con la acometida desarrollada por Martínez Silicio contra la Compañía de Jesús. ${ }^{8}$

A través de estas actuaciones, don Gaspar había evitado verse alejado de la Corte como había sucedido con el resto de los protegidos de Tavera. Sin embargo, su turno llegaba cuando, en 1554, fue nombrado para cubrir la plaza de auditor correspondiente a la Corona de Castilla en el Sacro Tribunal de la Rota. La protección que Fernando de Valdés dispensaba a Diego de Simancas facilitó que éste pudiese eludir el nombramiento realizado por el príncipe Felipe, que designaba a Quiroga como segunda opción. Por otra parte, su provisión contaba con el beneplácito de Martínez Silicio quien podía contar así con la presencia en Roma de un excelente especialista que obtuviese la aprobación del nuevo papa de los estatutos de limpieza de sangre de la catedral de Toledo. De la misma manera, el cabildo designaba a don Gaspar su procurador ante la Santa Sede. ${ }^{9}$

Si la marcha de Quiroga no hacía albergar augurios favorables sobre su futuro político, lo cierto fue que la estancia en Roma sería esencial para cimentar su posterior medro. Así, entre 1555 y 1559, incrementaba su cercanía a Ignacio de Loyola, cuya compañía frecuentaba con cotidianeidad, y quien medió para que las relaciones entre el auditor y el pontífice Paulo IV se desarrollasen de manera conveniente para los intereses de don Gaspar. Así, lograba la perseguida aprobación de los estatutos de limpieza de sangre junto a la ostentación de pingües beneficios eclesiásticos por nombramiento papal. ${ }^{10}$ Del mismo modo, su vinculación a la Compañía de Jesús sirvió para que Gaspar de Quiroga pudiese iniciar contactos con Ruy Gómez de Silva, y procurar así su integración en la

\footnotetext{
8 Henar PizARRo Llorente, op. cit., cap. 3.

${ }^{9}$ BCSV, Ms. nº 16, fol. 143r-v; ACT, Actas capitulares, tomo 9, fols. 229v-230r, 247v, 248r; Pedro SALAZAR Y MENDOZA, op. cit., 290-291.

${ }^{10}$ Ib., 291; BN, Ms. 13.044, fol. 129r; Diego CASTeJón y FonseCA, Primacía de la Santa Iglesia de Toledo. Madrid 1625, 1132; Albert A. Sicroff, Los estatutos de limpieza de sangre. Las controversias entre los siglos XV y XVI. Madrid, Taurus, 1985, 170-172.
}

Hispania Sacra, LXII

126, julio-diciembre 2010, 563-619, ISSN: 0018-215-X 
ascendente facción ebolista. ${ }^{11}$ El respaldo procurado por Francisco de Borja y el intento por parte de dicho «partido» de dominar la política de los territorios italianos procuraban a Quiroga el desempeño de su primer oficio relacionado con la administración de la Monarquía. En 1559, fue encargado de realizar una visita al Reino de Nápoles, actividad en la que se ocupó durante cuatro años. ${ }^{12}$

Cuando, en abril de 1564, don Gaspar retornaba a la Corte para finalizar los trámites concernientes a su actuación napolitana, encontraba una situación muy diferente en relación a las facciones cortesanas. El declive político de Fernando de Valdés, el auge del grupo ebolista, y sobre todo, la confianza otorgada por Felipe II a Diego de Espinosa para poner en marcha un proceso de reformas, supusieron para Quiroga la oportunidad de incorporarse a las actividades desplegadas por este. Si bien nunca formó parte de su grupo clientelar, se sumaba al grupo de letrados de los que Espinosa se sirvió para llevar a cabo dichas actuaciones. Así, la cooperación de don Gaspar se desarrollaba en varios ámbitos: como miembro del consejo de Castilla, como consejero de Inquisición, como integrante de la «Junta Magna», como visitador del Consejo de Cruzada, y en el ejercicio de la presidencia interina del Consejo de Italia, que ocupaba entre 1567 y $1571 . .^{13}$

No obstante, Quiroga retomaba su relación con la iglesia de Toledo vinculada a su labor como consejero de Inquisición, puesto que intervenía en el colofón del proceso hispano del arzobispo Bartolomé de Carranza. Por otra parte, don Gaspar se encontraba familiarizado con los avatares del mismo, puesto que, durante su estancia en Roma como auditor de la Rota, había frecuentado la compañía del deán de Oviedo, sobrino de Fernando de Valdés, y del procurador del Santo Oficio Juan de Bedoya..$^{14}$ En mayo de 1565 , se encargaba de elevar un informe realizado por Martín de Azpilcueta en relación con la prisión sufrida por el prelado, las quejas presentadas por este, y las opiniones del letrado sobre el devenir de a causa. ${ }^{15}$ El inicio del proceso romano abría la posibilidad de que don Gaspar fuese enviado a Roma junto al reo con el objetivo de obtener una sentencia condenatoria acorde a los intereses del monarca. Su conocimiento de

\footnotetext{
${ }^{11}$ Sobre la relación existente entre los miembros más destacados del «partido ebolista» y los jesuitas, véase, José Martínez Millán y Carlos Javier de Carlos Morales (Coord.), Felipe II (15271598). La configuración de la Monarquía hispana. Junta de Castilla y León 1998, 83.

${ }^{12}$ En torno algunos aspectos de la misma, véase, Henar PiZARro LlORENTE, «La visita al Reino de Nápoles de 1559: el enfrentamiento entre Gaspar de Quiroga y Juan de Soto». P. FERnÁndeZ AlbalAdejo, J. Martínez Millán, V. Pinto Crespo, Política, religión e Inquisición en la España Moderna. Universidad Autónoma de Madrid 1996, 567-586.

13 Sobre las actuaciones concretas desarrolladas por Quiroga en estos ámbitos, véase, Id., Un gran patrón...123-207.

14 José Ignacio Tellechea Idígoras, Fray Bartolomé de Carranza. Documentos históricos. Madrid 1962, I, 212.

15 BL, Add., 28.452, fols. 248r-254v.
} 
la causa, unido a sus buenas relaciones con los miembros de la Curia, y su habilidad como jurista hacían de don Gaspar un candidato idóneo para cumplir con este cometido. Sin embargo, en esta ocasión, lograba mantenerse ocupado en la Corte, acompañando al rey a Córdoba con motivo de la revuelta de los moriscos granadinos. ${ }^{16}$

Por otra parte, Quiroga hubo de solventar los problemas que surgieron en relación con el canonicato que ostentaba en la catedral de Toledo. Su promoción al Consejo de Inquisición, en noviembre de 1565, le habilitaba para seguir cobrando los frutos de esta prebenda sin tener que cumplir con la obligada residencia. ${ }^{17}$ Ante la reclamación presentada por don Gaspar, el cabildo se mostró dividido entre aquellos que estimaban conveniente acceder a la misma y los detractores de la concesión. Sin embargo, la oposición inicial desaparecía ante el respaldo que el propio rey y el Inquisidor General prestaban a esta solicitud. El cabildo decidía designar al licenciado Ibarra para que acudiese a negociar directamente con Quiroga la cuantía y el periodo a contabilizar de los emolumentos a percibir. No obstante, Quiroga rechazaba la oferta inicial del consistorio, lo que hacía fracasar la pretendida concertación. La determinación del cabildo fue resistirse al pago requerido, por lo que enviaron diversos comisionados a la Corte con ánimo de reorientar el asunto, pero los poderosos apoyos de Quiroga y las complicaciones que se podían derivar para el capítulo determinaron que, finalmente, la mayor parte de sus integrantes se mostrasen favorables a que don Gaspar percibiese dichas rentas. También se vieron inutilizadas las actuaciones que el cabildo había realizado en Roma, pues la intervención del auditor de la Cámara apostólica se vio atajada por la actuación del Consejo Real. ${ }^{18}$

Así pues, finalizado el largo litigio, don Gaspar pudo ver satisfechas sus pretensiones económicas referidas al canonicato toledano. Cuando fue promovido al obispado de Cuenca en 1571, hacía resignación del mismo en manos del papa Pío V. ${ }^{19}$ Pocos años después, se iniciaba el encumbramiento político de Quiroga, quien, integrado en la facción cortesana «papista», accedía al cargo de Inquisidor General en 1573, al de consejero de Estado, y, como hemos señalado, sustituía al frente del arzobispado de Toledo al fallecido Carranza en 1577. La culminación de su ascendente carrera eclesiástica se producía con su provisión como Cardenal de Santa Balbina en diciembre de 1578.

${ }^{16}$ Enrique Llamas Martínez, «Documentos Mss sobre la causa del arzobispo de Toledo fray Bartolomé de Carranza existente en el British Museum». Studium legionense 12 (1971), 264-265.

${ }^{17}$ En torno a esta cuestión, véase, José MARTínEz MiLÁN, «Las canonjías inquisitoriales: un problema de jurisdicción entre la Iglesia y la Monarquía (1480-1700). Hispania Sacra 34 (1982), 21-28; Id., La Hacienda de la Inquisición (1478-1700). Madrid, CSIC, 1984, 99-123.

${ }_{18}$ ACT, Actas capitulares, tomo 12, fols. 156r, 226r-227v, 234r-246v, 253v-254v, 274r-275r, 305r307 r.

19 Ib., tomo 15 , fol. 291 r.

Hispania Sacra, LXII

126, julio-diciembre 2010, 563-619, ISSN: 0018-215-X 
No obstante, durante estos años, don Gaspar no había perdido el contacto con los asuntos relacionados con la iglesia toledana, pues su nombramiento como Inquisidor General había condicionado el seguimiento del proceso que se desarrollaba en Roma contra Carranza, así como su atención al espinoso asunto de la administración de las rentas del arzobispado durante la causa del arzobispo. Aunque el sostenimiento económico de dicha causa precisaba importantes sumas de dinero, las elevadas rentas de la iglesia toledana cubrían sobradamente los costes de la misma. Sin embargo, a las quejas proferidas por los servidores desplazados con el reo ante el impago de sus salarios, se sumaron las voces que criticaban la dilación en la resolución de este proceso a causa de los beneficios económicos que Felipe II estaba obteniendo de los recursos de la iglesia toledana. Esta situación vino a complicarse con la muerte de Carranza, puesto que la invalidación de su testamento se convertía en el motivo de una nueva disputa jurisdiccional entre la Monarquía hispana y la Santa Sede. Así pues, el nuncio Ormaneto y Gaspar de Quiroga fueron encargados de revisar las cuentas pertenecientes al arzobispado desde el día del apresamiento del prelado hasta el de su muerte, que habían sido gestionadas durante estos años por la Suprema y los administradores designados por el rey. El intento del papa de intervenir en los asuntos temporales de la iglesia forzaba a Felipe II a impedir esta iniciativa a través de la actuación del Consejo Real, pues la crisis económica que atravesaba la Monarquía y la repentina muerte de Carranza imposibilitaban que Felipe II tuviese capacidad para restituir a la iglesia toledana el dinero perteneciente a la misma que había invertido en diferentes asuntos ajenos a ésta. Quiroga, proveído nuevo arzobispo, fue la persona clave para orientar las negociaciones convenientemente, primero con Ormaneto, y, después de su muerte, acaecida en junio de 1577, con el nuevo nuncio Felipe Sega y con el colector Juan Bautista Cannobio. Finalizadas las cuentas referidas al proceso inquisitorial con Lope de Avellaneda, el embajador en Roma, Juan de Zúñiga, recibía la orden del rey de solicitar al pontífice la concesión de los fondos tomados de las rentas eclesiásticas. No obstante, la evolución de las relaciones políticas entre la Monarquía hispana y la Santa Sede condicionó que este asunto permaneciese sin resolver durante los años siguientes. Al perjuicio económico para la iglesia toledana generado por la falta de reposición de este dinero hubo que sumar los beneficios económicos que el monarca obtuvo del privilegio otorgado por el papa Gregorio XIII, por el que recibía la facultad de enajenar rentas pertenecientes a cualquier iglesia catedral metropolitana, colegial o primacial por un importe anual inferior a cuarenta mil ducados. Sin duda, esta concesión tuvo especial repercusión en la archidiócesis toledana, significativamente en los años que Gaspar de Quiroga estuvo al frente de esta prelacía. ${ }^{20}$

${ }^{20}$ En relación a estas cuestiones, véase, Henar PiZARro Llorente, Un gran patrón... 365-389. 


\section{LA EVOLUCIÓN DE LOS MIEMBROS DEL CABILDO CATEDRALICIO}

El nuevo prelado acudía a tomar posesión de la dignidad en la sede arzobispal en marzo de $1578 .{ }^{21}$ Su preocupación se centraba en el estado en el que se encontraba la iglesia toledana después de tantos años privada de prelado y en la aplicación de la reforma que se derivaba de los decretos emanados del Concilio de Trento, a cuya consecución había prestado especial atención en la labor desarrollada como obispo de Cuenca. En lo que se refiere al cabildo catedralicio, Quiroga insistía en que se debía ajustar a dicha reglamentación a través de observar que todos los canónigos estuviesen ordenados en misa, y se establecía que ni los dichos beneficiados ni los racioneros podrían ausentarse de sus prebendas por un espacio temporal superior a tres meses en el mismo año. ${ }^{22}$ En este sentido, el consistorio representó al arzobispo la conveniencia de mantener vigente lo recogido al respecto en las constituciones de la iglesia de Toledo, pues favorecían en mayor medida el cumplimiento de la obligada residencia que la disposiciones tridentinas. Así mismo, representaban la conveniencia de ajustarse a éstas en lo concerniente a las distribuciones cotidianas, que se verían incrementadas..$^{23}$

Con estas actuaciones, entre otras, don Gaspar establecía las bases de unas buenas relaciones con el cabildo catedralicio, que se vieron alteradas en muy pocas ocasiones. En este sentido, la labor de patronazgo desarrollada por el prelado facilitaba este entendimiento, aun cuando Quiroga admitía a su servicio a todos aquellos que había ocupado cargos o dignidades en la prelacía precedente. ${ }^{24}$ Entre estos, destacaba un grupo de significados humanistas que, vinculados a la Universidad de Alcalá de Henares, dinamizaron el ambiente cultural de Toledo. Sus iniciativas en el ámbito de la realización de estudios y en el mecenazgo de las artes fueron apoyadas por el arzobispo. Dentro de este selecto grupo, cabe destacar a Antonio de Covarrubias, maestrescuela de la Universidad de Santa Catalina, ${ }^{25}$ y a los hermanos Diego y Luis de Castilla, deán y arcediano

${ }^{21}$ Sobre los actos que tuvieron lugar, véase, ACT, Actas capitulares, tomo 16 , fols. 179v-182v; BN, Ms. 4336, fols. $182 \mathrm{v}-183 \mathrm{r}$.

22 No reflejamos en el presente trabajo la evolución histórica del cabildo toledano, que ha sido abordada en otros estudios. En este sentido, véase, María José Lop OTín, El cabildo catedralicio de Toledo en el siglo XV: aspectos institucionales y sociológicos. Tesis doctoral, UCM, 2002; Ángel FERNÁNDEZ Collado, La catedral de Toledo en el siglo XVI. Vida, arte y personas. Toledo, Diputación Provincial de Toledo, 1999; Ramón SÁncheZ GonZÁLEZ, Iglesia y sociedad en la Castilla Moderna: el cabildo catedralicio de la sede primada (siglo XVII). Cuenca, Ayuntamiento de Toledo, 2000.

23 ACT, Actas capitulares, tomo 16, fols. 184r-189v.

24 Jerónimo Román de la Higuera, op . cit., fol. 204; Pedro Salazar y Mendoza, op. cit. 79-80. Sobre los canónigos integrados en el cabildo cuando don Gaspar ocupa la mitra.

${ }^{25}$ Hermano de Diego de Covarrubias, obispo de Segovia y presidente del Consejo Real, estudió Leyes en Salamanca, donde obtuvo la licenciatura en 1556. En 1561, era proveído oidor de la Chanci-

Hispania Sacra, LXII

126, julio-diciembre 2010, 563-619, ISSN: 0018-215-X 
de Cuenca respectivamente, quienes actuaron como protectores de El Greco. ${ }^{26}$ En este sentido, Antonio de Covarrubias fue proveído por el pontífice en la canonjía vaca por la promoción de Alonso Delgado al obispado de Astorga. Presentaba en el cabildo las bulas correspondientes en septiembre de 1580.27

Respecto a las nuevas incorporaciones, el doctor Alonso Hondegardo accedía a una canonjía doctoral por el fallecimiento del licenciado Valdivieso. Igualmente, la muerte del doctor Barriovero a finales de 1577 posibilitaba que Alonso de Mendoza, chartre de la iglesia de Alcalá de Henares, pasase a ocupar la canonjía magistral. ${ }^{28}$ Del mismo modo, la promoción del doctor Velasco al obispado de Osma tenía como consecuencia la provisión de la canonjía de lectura que ostentaba en Gabriel de Cárdenas, maestro en Teología de la Universidad de Salamanca. ${ }^{29}$ En relación con estas dos últimas elecciones, se había generado una situación de cierta tensión entre el cabildo y Juan de Obregón, vicario nombrado por el arzobispo para que asistiese a todos los actos relacionados con la elección y votase en su nombre. Como medio para poner fin a esta práctica irregular y coactiva, en abril de 1579 , el consistorio solicitaba al arzobispo que Obregón accediese a una canonjía de penitenciario. No obstante, don Gaspar prefirió proveer en la misma a Juan Calderón. La oportunidad para el vicario general se presentaba cuando fue designado para cubrir la vacante pro-

llería de Granada, acudiendo, al año siguiente, a la celebración del Concilio de Trento. En 1569, comenzó a actuar como oidor en la Chancillería de Valladolid, siendo nominado consejero real en 1573. El impedimento provocado por su sordera motivó que Felipe II le apartase de esta función, obteniendo nombramiento de canónigo en Toledo y maestrescuela de la Universidad. Ocupando este cargo, se puso en concurso la plaza de profesor de griego. Entre los cuatro candidatos presentados se encontraba Andrés Schott, flamenco llegado a la ciudad en 1579, y protegido de Gaspar de Quiroga, quien le hospedó en el palacio arzobispal. En torno a Diego de Covarrubias y el grupo de humanistas toledanos, véase, Gregorio DE ANDRÉS, «El helenismo del canónigo toledano Antonio de Covarrubias. Un capítulo del humanismo en Toledo en el siglo XVI». Hispania Sacra 40 (1988), pp, 237-271; José FernáNDeZ MontaÑa, Los Covarrubias. Madrid, Hijos de Gregorio del Amo, 1935, pp, 67-98.

${ }^{26}$ Gregorio DE ANDRÉs, «El arcediano de Cuenca don Luis de Castilla (?1618) protector del Greco y su biblioteca manuscrita». Hispania Sacra 35 (1983), pp, 87-141; Verardo GARCía Rey, El deán don Diego de Castilla y la reconstrucción de Santo Domingo el Antiguo de Toledo. Toledo, A. Medina, 1927.

${ }^{27}$ ACT, Actas capitulares, tomo 16, fols. 389v-390r, 395r-396r.

28 Ángel FeRnÁNDEZ Collado, La catedral de Toledo... 78, 83-84. La vinculación y amistad de Gaspar de Quiroga con la familia Mendoza se mantuvo a lo largo de todas su vida (Henar PizARro LLORENTE, Un gran patrón... passim).

29 Ángel Fernández Collado, La catedral de Toledo... 68. Además de Cárdenas, opositaban a la canonjía: Pero Martínez, canónigo de Sigüenza y catedrático de Prima en Teología, el doctor Barrio, canónico y catedrático de Sigüenza, el doctor Calderón, catedrático de Prima de la Universidad de Alcalá, Alonso Pérez, catedrático de Sagrada Escritura de Plasencia, el doctor Juan Pérez Valenzuela, canónigo de Córdoba, el doctor Molina, canónigo de Sagrada Escritura de Antequera y el doctor Juan Cantero, canónigo y catedrático de Escritura de Alcalá de Henares (ACT, Actas capitulares, tomo 16, fols. 420v). 
ducida por la muerte de Ramiro de Guzmán. De esta manera, Calderón cubría la plaza vaca por la promoción de Jerónimo Manrique a la mitra de Salamanca. ${ }^{30}$ La renuncia de Juan de Guzmán posibilitaba que Quiroga procediese al nombramiento de Antonio Manrique, mientras que Francisco García de Valloboso ocupaba la vacante producida por el óbito de Miguel de Silva. El fallecido doctor Peralta fue relevado por Juan de Alarcón. De la misma manera, Pedro de Quiroga, inquisidor de Valladolid y sobrino del arzobispo fue nombrado canónigo y tesorero en lugar de Pedro González de Mendoza a finales de 1579. No obstante, su ocupación en el Santo Oficio provocaba que permaneciese ausente de la iglesia toledana durante meses, por lo que fue necesario instar al consistorio para que se le tuviese por presente. También tuvo problemas en la percepción de los frutos de su canonjía el licenciado Ibarra, quien ocupaba el cargo de consultor en el mismo tribunal inquisitorial. ${ }^{31}$ Las provisiones de canónigos en estos primeros años se completaban con la designación por parte del papa Gregorio XIII de Bernardino de Mendoza en la canonjía que había sido ostentada por Diego de Guzmán.

Por otra parte, Quiroga procedía en relación con los racioneros y clerizones de igual manera, pues procuraba una renovación de los mismos..$^{32}$ En este sentido, prestaba especial atención a que las provisiones en los beneficios curados recayesen en personas idóneas en relación a lo dispuesto por los decretos tridentinos. Así mismo, los canónigos catedralicios también procuraron favorecer a sus deudos en los nombramientos de capellanes, lo que desató cierta pugna entre ellos en referencia a las atribuciones correspondientes al que desempeñaba la función de semanero mayor. ${ }^{33}$ Igualmente, la capacidad de patronazgo de Quiroga para los prebendados toledanos también se extendía a la Capilla Real. Así, Dionisio Ruiz de la Peña obtenía el título de capellán real en febrero de 1576. ${ }^{34}$ Canónigo de la iglesia Colegial de Talavera de la Reina, era amigo del predicador real fray Alonso de Orozco, al que visitaba junto a don Gaspar. ${ }^{35} \mathrm{Se}-$ cretario y confesor del Inquisidor General, fue nombrado racionero de la catedral toledana en 1580. Al año siguiente, fue el mediador de Teresa de Jesús en su comunicación con el arzobispo de Toledo en relación con el deseo de Elena

\footnotetext{
${ }^{30} \mathrm{Ib}$. , fols. $282 \mathrm{r}, 285 \mathrm{v}-286 \mathrm{r}$.

${ }^{31} \mathrm{Ib}$., fols. 349v-350r, 353v-356r, 359r.

32 Véase el Apéndice.

${ }^{33}$ ACT, Actas capitulares, tomo 16, fols. 272v-273r, 275r, 292r, 309v, 318r. Sobre los canónigos citados, véase, Ángel FERNÁNDEZ Collado, La catedral de Toledo... 61, 67, 77, 82, 84, 95.

${ }^{34}$ AGS, CSR, leg. 121, nº 215; José Martínez Millán y Santiago Fernández Conti (Dirs.), La Monarquía de Felipe II: la Casa Real. Madrid, Fundación MAPFRE, 2005, II, 405.

35 Tenía un buen conocimiento de los familiares de Orozco por su vinculación a Talavera de la Reina. Fue uno de los declarantes en la Información sumaria de su proceso de beatificación (Luciano RUBIO, Beato Alonso de Orozco.Biografía. I. Madrid, Escurialenses, 1991, 56, 352).
} 
de Quiroga de profesar como monja carmelita. La decisión de su sobrina disgustaba al prelado, por lo que Teresa de Jesús procuraba aclarar que no había influido en la decisión de doña Elena, y que, en todo caso, había procurado estorbar su deseo, puesto que tampoco estimaba conveniente el ingreso en un convento de una viuda que dejaba hijos dependientes de sus cuidados. Por otra parte, esta cuestión no favorecía su intención de obtener la autorización del arzobispo para proceder a la fundación de un convento en Madrid. ${ }^{36}$

La caída en desgracia de Antonio Pérez supuso para Quiroga el relegamiento político. La ofensiva desplegada por la facción «castellanista» para dominar los espacios políticos controlados por sus opositores, el «perecismo» mostrado por don Gaspar, así como sus opiniones en torno a la anexión de Portugal, poco coincidentes con los deseos de Felipe II, propiciaban que Quiroga buscase refugio en su prelacía. ${ }^{37}$ Así, en marzo de 1580 llegaba a Toledo con la intención de llevar a cabo diversas actuaciones en el obispado en aras de continuar con la actividad reformística iniciada, como la realización de varias visitas, que generaron algunas tensiones con el cabildo, y sobre todo, la celebración de sínodo diocesano en ese mismo año y de un concilio provincial en $1582 .{ }^{38}$ Igualmente, continuaba con la labor de patronazgo a favor de sus familiares y amigos a través de su promoción a las plazas que vacaban en el cabildo. La muerte de Diego López de Torquemada posibilitaba el nombramiento para cubrir su canonjía de un miembro del Consejo de la Dignidad, el licenciado Diego de Virviesca. Como en ocasiones precedentes, don Gaspar participaba en la votación mediante el vicario Juan de Obregón. 39 Igualmente, Quiroga promocionaba a la dignidad de canónigo a dos colaboradores, el vicario del Coro Pedro de Ayala, y a Gabriel Suárez de Toledo, que ocupaba la plaza resignada por Pedro Velarde, protegido del prelado. ${ }^{40}$ La provisión de

\footnotetext{
36 Santa Teresa de Jesús, Epistolario. Madrid, Editorial de Espiritualidad, 1984, cartas 380, 382 , 390, 790-792, 794-795, 808-809. Posteriormente, la resistencia del Cardenal fue vencida por la tenacidad de doña Elena, que alcanzaba su propósito de ingresar en el convento de Medina del Campo. Solucionado este asunto, Teresa de Jesús reiteraba ante Dionisio de la Peña su esperanza de conseguir la autorización de Quiroga para llevar a cabo sus proyectos de fundación en Madrid (ib., cartas 412, 434, 850-851, 880-881).

${ }^{37}$ En torno a estas cuestiones, véase, Henar PIZARro LlORENTE, Un gran patrón .. 407-452.

38 Ibidem 452-494. En torno a dichas actuaciones, véase, Ángel FERNÁNDEZ Collado, Concilios toledanos postridentinos. Toledo, Diputación Provincial de Toledo, 1996. Segunda Parte; Henar PIZARRO LLORENTE, Un gran patrón... 467-494.

39 Los opositores a la canonjía doctoral eran: Andrés de Córdoba, colegial de San Bartolomé y licenciado en Cánones, Andrés Martínez Manzano, canónigo doctoral de la iglesia de Sigüenza y doctor en Cánones por la universidad sita en dicha ciudad, Alonso de Anaya Pereira, colegial de Santa Cruz y doctor en Cánones por la Universidad de Valladolid, el licenciado Diego de Arellano y Zapata, canónigo doctoral de la iglesia de Coria, el licenciado Bonal, colegial de Santa Cruz, y el elegido Diego de Virviesca, sacerdote y licenciado en Cánones por la Universidad de Salamanca. En torno a esta elección, ACT, Actas capitulares, tomo 17, fols. 5v-6r, 11v, 15r.

${ }^{40} \mathrm{Ib}$., tomo 16 , fols. 392r-393v, 407r-v.
} 
familiares y personas cercanas al mismo se prolongaba durante 1581. Así, en febrero, notificaba al consistorio su provisión Juan Bautista Pérez, fiel amigo de Quiroga, y en junio, el sobrino del arzobispo, llamado también Gaspar de Quiroga, ocupaba la vacante producida por el fallecimiento de Juan Barrionuevo. ${ }^{41}$ En el mismo mes, otro miembro del Consejo de la Dignidad, Antonio Morejón, también obtenía su promoción. En este sentido, cabe significar que la familia Morejón se encontraba emparentada con los Quiroga, y que, al año siguiente, don Antonio fue nombrado maestrescuela y vicario arzobispal de Alcalá de Henares..$^{42}$

La designación del licenciado Temiño como nuevo prelado abulense promocionaba a Juan Llano de Valdés a ocupar la canonjía que este abandonaba. El nombramiento, realizado a través de bulas apostólicas, encontró la oposición de cabildo por dos motivos. En primer lugar, la condición de consiliario de la Inquisición de Llano de Valdés le eximía de la obligada residencia, y, además, su vinculación al grupo «castellanista», $\mathrm{y}$, concretamente, al secretario Mateo Vázquez, desagradaba al consistorio. Si bien hubieron de admitir la provisión, a pesar de los intentos realizados para evitar la misma cuestionando la limpieza de sangre del candidato, su pronto fallecimiento conllevaba que su ocupación de la canonjía fuese muy breve. El arzobispo nombraba en su lugar a Juan de Aramayona, inquisidor del tribunal de Navarra. ${ }^{43}$ No obstante, su vinculación al cargo fue igualmente efímera, puesto que fallecía dos años después. Quiroga nombraba a Andrés Fernández, vicario general del arzobispado, para ocupar dicho canonicato. ${ }^{44}$

La muerte del doctor Hondegardo, a finales de 1582, convocaba a tres candidatos para cubrir la vacante de la canonjía doctoral. Los tres opositores lograban su objetivo de obtener una provisión en la iglesia toledana. Así, dicha plaza fue cubierta por el doctor Salvador Navarro, mientras que el óbito de Fernando de Ribadeneyra propiciaba el nombramiento de Alonso de Anaya Pereira. Así mismo, Pedro de Tapia fue proveído arcipreste de Santa Olalla. Mientras que el nombramiento de Anaya Pereira estaba relacionado con la inclinación de Quiroga por favorecer a los colegiales de Santa Cruz, centro vallisoletano en el que el prelado había realizado sus estudios, Pedro de Tapia iniciaba su medro a la sombra de Quiroga, a quien le unía su nacimiento en Madrigal de las Altas Torres. ${ }^{45}$ En este sentido, el prelado no olvidaba beneficiar a su familia. En junio

\footnotetext{
41 Ib. Tomo 17, fols. 40v-41r, 47r-48r; ib., tomo 18, fol. 115v. Sobre dichos canónigos, véase, Ángel FERNÁNDEZ COLLADO, La catedral de Toledo... 61-104.

42 AHN, Inq., libro 358, fol. 89v.

43 ACT, Actas capitulares, tomo 17, fol. 120r.

$44 \mathrm{Ib}$., tomo 18 , fols. 20r, $21 \mathrm{r}$.

$45 \mathrm{Ib}$, tomo 17 , fols. $165 \mathrm{v}, 176 \mathrm{v}-177 \mathrm{r}, 179 \mathrm{v}-181 \mathrm{r}$.
}

Hispania Sacra, LXII

126, julio-diciembre 2010, 563-619, ISSN: 0018-215-X 
de 1584, su sobrino Pedro de Quiroga obtenía el nombramiento de obrero de la iglesia de Toledo. Sin embargo, su fallecimiento unos meses después frustraba su ascendente trayectoria. Otro familiar del arzobispo, Martín de Alderete, fue designado para cubrir la canonjía vacante. A esta promoción de parientes se sumaba el deán de la iglesia de León Francisco de Monsalve, quien fue proveído canónigo en 1585.46 Por último, la muerte del licenciado Ibarra provocaba que Quiroga designase a Antonio Venegas Figueroa para ocupar el canonicato vacante. 47

Especial consideración merece la provisión del deanato de la iglesia toledana tras el fallecimiento de Diego del Castillo el 7 de noviembre de 1584. El cabildo nombraba de manera interina y por un espacio de dos meses al canónigo y arcediano de Talavera Juan de Mendoza para ocupar dicha dignidad. Unos meses después, Quiroga ratificaba este nombramiento, con lo que pasaba a convertirse en el nuevo deán. En este sentido, hemos de señalar que era hermano del duque del Infantado, así como la tradicional vinculación que don Gaspar mantenía con dicha familia, y que otro de los hermanos del mismo, Rodrigo de Mendoza, continuaba el pleito en relación a la titularidad del Adelantamiento de Cazorla. ${ }^{48}$

Si bien entre 1580 y 1584 la actividad de don Gaspar estuvo significativamente circunscrita a sus actuaciones en la iglesia toledana, pues procedía a la celebración de forma consecutiva de un sínodo diocesano y de un concilio provincial, su prolongada estancia en la misma estaba directamente vinculada a su relegamiento cortesano. Durante estos años, procuraba infructuosamente mejorar su relación con Mateo Vázquez. No obstante, su rehabilitación política llegaba a través de la mediación que el secretario del Consejo de Inquisición, el licenciado Arenillas de Reinoso, realizaba para que el prelado iniciase un acercamiento al conde de Chinchón, quien contaba con una creciente estimación por parte del rey.49 A pesar de que Quiroga colaboraba activamente con Chinchón para superar la postergación sufrida en los años precedentes, la evolución habida en el sistema de gobierno de la Monarquía condicionaba que don Gaspar no pudiese encontrar cabida en el nuevo funcionamiento, y, si bien se reincorporaba a las tareas políticas, nunca volvía a alcanzar las cotas de poder que había ostentando en los años precedentes. Reintegrado a las reuniones del Consejo de Estado, se ocupaba de la gobernación de los asuntos de Italia y rea-

\footnotetext{
$46 \mathrm{Ib}$., tomo 18 , fols. 106r, $143 \mathrm{r}-\mathrm{v}$.

$47 \mathrm{Ib}$, fols. $182 \mathrm{v}-183 \mathrm{r}$.

$48 \mathrm{Ib}$., tomo 17 , fols. $88 \mathrm{v}, 89 \mathrm{r}, 105 \mathrm{v}, 130 \mathrm{r}-131 \mathrm{v}$.

49 Santiago Fernández Conti, «La nobleza cortesana: don Diego de Cabrera y Bobadilla, tercer conde de Chinchón». José Martínez Millán (Dir.), La Corte de Felipe II. Madrid, Alianza 1994, 229 270 .
} 
lizaba sus últimas actuaciones como Inquisidor General, entre las que cabe destacar el proceso instruido contra el secretario Antonio Pérez y las juntas reunidas para tratar la problemática morisca. .0

No obstante, su merma de poder también quedaba patente en el ámbito inquisitorial, cuyos asuntos quedaban bajo el dominio de la facción «castellanista». La diferencia entre los designios más radicalizados de este grupo y los planteamientos mantenidos por don Gaspar se ponía de manifiesto en diversos ámbitos. Sin embargo, queremos resaltar la cuestión referida a la aparición de profetas y visionarios que, a través de la formulación de sus profecías y visiones, realizaban una fuerte crítica a la política desarrollada por Felipe II. Así, ante la dureza esgrimida por los «castellanistas» para atajar la expansión de estos nefastos augurios, aludiendo a su carácter herético para posibilitar su represión por el Santo Oficio, el Inquisidor General procedía sin rigor. En este sentido, hemos de destacar la vinculación de Alonso de Mendoza, canónigo de la catedral de Toledo y abad de San Vicente, con dos personajes que propagaban estas manifestaciones proféticas: Miguel de Piédrola y Beaumont, y Lucrecia León. Alonso de Mendoza recurría al arzobispo toledano con la finalidad de obtener ayuda para sus amigos. La actuación de Quiroga daba margen al confesor Diego de Chaves para poner en duda la capacidad e intencionalidad del Inquisidor General al tratar este asunto, pues, por una parte, se había alterado el secreto procesal en el caso de Piedrola a causa de las informaciones realizadas por Mendoza y por Quiroga a distintas instancias en Roma, mientras que la liberación de Lucrecia León hacía que el confesor acusase a Quiroga de no emplearse con la dureza necesaria en este asunto a causa de la relación de estos sueños y visiones con Antonio Pérez, y ser el arzobispo un reconocido «perecista». Si bien no se puede constatar que se tratase de una conspiración de un grupo constituido para favorecer al secretario, sí existían viejas conexiones entre ambos. Ciertamente, los procesos inquisitoriales contra Antonio Pérez y contra Lucrecia León y sus seguidores se desarrollaron de forma paralela. En ambos casos, el Inquisidor General hubo de plegarse a los designios reales. ${ }^{51}$

La debilidad política de Quiroga también se ponía de manifiesto en los asuntos de la iglesia toledana, y, concretamente, en su capacidad de introducir en el

${ }^{50}$ En torno a la recuperación política de Quiroga y las actividades que desarrolló en estos años, véase, Henar PIZARro LloRente, Un gran patrón... 511-541.

${ }^{51}$ Ibidem 542-549. Sobre el trato de favor de que gozó Alonso de Mendoza cuando fue encarcelado por el tribunal inquisitorial de Toledo, véase, Vicente BELTRÁn DE HEREDIA, «Un grupo de visionarios y pseudoprofetas que actúa durante los últimos años de Felipe II». Miscelánea Beltrán de Heredia. Salamanca, Ope, 1972, III, 335-405; Richard L. Kagan, Los sueños de Lucrecia. Política y profecía en la España del siglo XVI. Madrid, Nerea, 1991; Antonio CASTILlo GóMEZ, «Pasiones solitarias. Lectores y lecturas en las cárceles inquisitoriales del Siglo de Oro». Península. Revista de Estudios Ibéricos 3 (2006), 142-143, 145.

Hispania Sacra, LXII

126, julio-diciembre 2010, 563-619, ISSN: 0018-215-X 
cabildo catedralicio a sus protegidos. Sin duda, esto provocaba que la última etapa del prelado al frente del arzobispado resultase de mayor conflictividad con el mismo, lo que supuso una ruptura respecto a la evolución anterior. Quiroga hubo de conformarse con tratar de asegurar ciertos beneficios a sus familiares, y asumir el influjo que comenzaron a ejercer miembros de su arzobispado que ascendían en la estimación regia, como sucedía con García de Loaysa. Así, entre 1587 y 1590, el arzobispo proveía en las correspondientes canonjías a García de Mendoza, a quien designaba igualmente como capiscol. No obstante, unos meses después, la capiscolía pasaba a manos de Gaspar de Quiroga, sobrino del prelado. También proveía en un canonicato a Juan de Zúñiga, perteneciente al Consejo de Inquisición y natural de la villa natal de Quiroga, y a sus sobrinos Juan de Quiroga, Álvaro de Monsalve y Francisco Morejón, quien accedía a la dignidad de Tesorero General de la Iglesia de Toledo en 1591, mientras que otros de sus parientes obtenías distintos cargos y dignidades. Así, Martín de Alderete ejercía el cargo de vicetesorero y la vicaría del coro, y Francisco Monsalve era nombrado por el prelado Obrero Mayor en 1592. La promoción de canónigos por parte de Quiroga se completaba con los nombramientos de Gregorio Bravo de Sotomayor, quien había colaborado activamente con el arzobispo en la consecución de las visitas a Sicilia y al Consejo de Cruzada, de Alonso Serrano, perteneciente al Consejo de la Dignidad, y de Gabriel Ortiz de Sotomayor, quien sustituía al fallecido Bravo de Sotomayor. ${ }^{52}$

A partir de 1590, las provisiones de los canónigos comenzaron a reflejar la presencia de otras influencias en el arzobispado diferentes a las del prelado. Así, Francisco Ruiz de Velasco, hermano del Condestable, obtenía el canonicato por la petición realizada en su favor por el secretario Mateo Vázquez y García de Loaysa. A este se unían Francisco de Espinosa, Antonio de Cordones, Gabriel Pacheco, hermano del marqués de Villena, y Matías Rodríguez, quien ocupaba una canonjía de lectura sagrada. ${ }^{53} \mathrm{~A}$ las únicas personas que lograba promocionar el prelado fueron Jerónimo Pacheco, quien servía a don Gaspar como mayordomo, y el inquisidor de Cuenca Francisco de Arganda, que era un antiguo protegido del Inquisidor General. La causa de tan escasa influencia estaba en la mermada capacidad de Quiroga para el patronazgo, pues, como afirmaba el secretario Mateo Vázquez, las pocas personas con las que podía contar don Gaspar, pertenecientes a su linaje y casa, así como su declinado poder favo-

\footnotetext{
52 Sobre la fecha exacta de los nombramientos, consúltese el Apéndice.

${ }^{53}$ Los opositores a dicha canonjía fueron: el licenciado Álvaro Pizaño de Palacios, canónigo de la iglesia magistral de Antequera, el licenciado Rejón, canónigo de Zamora, el doctor Castillo, canónigo de Guadix, el doctor Terrones, canónigo de Granada, el doctor Juan de Palacios, canónigo de Salamanca, el doctor Juan Berrueco de Samaniego, canónigo de Tuy, el doctor Pastrana, prior de San Ildefonso de Jaén, el doctor Juan Gutiérrez, canónigo de Coria, el doctor Francisco Farfán, canónigo de Salamanca y el doctor Matías Rodríguez, canónigo de Jaén (ACT, Actas capitulares, tomo 20, fol. 203r).
} 
recían las actuaciones externas..$^{54}$ Las últimas designaciones de canónigos realizadas durante la prelacía de Quiroga recayeron en Pedro Deza, sobrino del Cardenal Deza, en Antonio Canseco de Quiñones, en Pedro de Castro, 55 y en Juan Pérez de Valenzuela, que ocupó la canonjía doctoral vacante por el fallecimiento del doctor Navarro. .56

Por otra parte, la nominación de coadjutores en algunas canonjías por parte del pontífice provocó que se generase cierta tensión entre el cabildo toledano y la Santa Sede. Así, el 1 de junio de 1587, se presentaron al consistorio las bulas y letras apostólicas en favor de Miguel de Salazar, vecino de Toledo, por las que era nombrado coadjutor con futura sucesión al canonicato y prebenda del protonotario Miguel Díaz. El cabildo comunicó a Quiroga esta situación, y procedió a apelar esta medida..$^{57}$ Por otra parte, Mateo Vázquez informaba a García de Loaysa de la curiosa situación producida, puesto que el canónigo Miguel Díaz tenía un hijo que también era canónigo de Toledo, el licenciado Bautista Vélez, mientras que Miguel de Salazar era su nieto. Según refería el secretario, había que esgrimir ante el nuncio y el papa esta cuestión para no obedecer la bula..$^{58}$ Finalmente, el consistorio hubo de acatar el mandato apostólico cuando, en marzo de 1590, Miguel de Salazar volvió a presentar en el mismo los documentos que acreditaban su designación. ${ }^{59}$ Sin embargo, esta situación se complicó cuando, el 31 de mayo de dicho año, Alonso Gómez, clérigo de la diócesis de Toledo, acudió al cabildo con unas bulas y letras apostólicas por las que era nominado coadjutor del canónigo Miguel Díaz, quedando derogado el nombramiento que para este cargo se había dado a Miguel de Salazar. ${ }^{60}$ Así mismo, en noviembre de 1587, Quiroga representaba al embajador en Roma, el conde de Olivares, el agravio que había recibido por el novedoso comportamiento del

\footnotetext{
${ }^{54}$ IVDJ, envío 55 (caja 73), nº 65, 69.

55 Los opositores a dicha canonjía fueron: el licenciado Gómez de Salamanca, colegial del Real de Granada, el licenciado Pizaño de Palacios, el licenciado Blas de Samaniego, canónigo de lectura en Valladolid, el maestro Juan Alonso Curiel, catedrático de Biblia en Salamanca y el doctor Pedro de Castro, canónigo de la iglesia magistral de Ávila (ACT, Actas capitulares, tomo 19, s.f.; ib., tomo 21, fol. $154 \mathrm{r}-\mathrm{v})$.

56 Los opositores a la misma fueron: Francisco Fernández de Córdoba, catedrático de Cánones en Alcalá de Henares, el doctor Salazar de Mendoza, el doctor Chaves de Mora, colegial de San Bartolomé, el licenciado Juan Pérez de Valenzuela, catedrático de la Universidad de Valladolid, el licenciado Diego de Loriana Escobar, rector de la iglesia parroquial de Santiago en la Puebla de Alcocer, el doctor Francisco García Ximénez, colegial de Santa Cruz y canónigo doctoral de Valladolid, el licenciado Antonio Coello de Portugal, canónigo doctoral de Cartagena, el doctor Domingo de Mendieta, canónigo doctoral de Osma, el doctor Tolentino de Vivar, catedrático de Prima de cánones en Osma, y el licenciado Juan Vela de Acuña, colegial de San Bartolomé (ib., tomo 19, s.f.).

${ }^{57} \mathrm{Ib}$., fols. 32v-33r, 34r, 39v, 41r.

58 AZ, carp. $142, \mathrm{n}^{\circ} 149$.

59 ACT, Actas capitulares, tomo 20, fols. 22r-v, $24 \mathrm{r}$.

$60 \mathrm{Ib}$., fols. 48v-51v, 52v-53r.
}

Hispania Sacra, LXII

126, julio-diciembre 2010, 563-619, ISSN: 0018-215-X 
pontífice respecto a la provisión de los beneficios simples pertenecientes a Juan Téllez, muerto en Génova, derogando el indulto de Gregorio XIII en favor del prelado para que pudiese realizar estos nombramientos. ${ }^{61}$

Sin embargo, el cabildo mostró una actitud diferente cuando, en septiembre de 1589, Ginés de Soto, clérigo presbítero perteneciente al arzobispado toledano, exhibió ante el mismo los documentos pontificios que le proveían como coadjutor con futura sucesión en la canonjía que ostentaba Rodrigo de Mendoza, puesto que obedecieron con prontitud la nominación. La anuencia del cabildo contrastaba con el mal acogimiento que tuvo esta actuación por parte de Gaspar de Quiroga. ${ }^{62}$ No obstante, los mayores problemas estuvieron relacionados con el nombramiento de Juan de Mendoza como Cardenal, pues además de su canonjía, ostentaba las dignidades de deán y arcediano de Talavera. Si bien, como hemos referido, Quiroga designaba en esta a su sobrino Gaspar, en febrero de 1592, proveía como nuevo deán a Pedro de Carvajal, mientras que la canonjía recaía en el citado Jerónimo de Miranda Vivero por mandato apostólico. ${ }^{63}$

\section{APÉNDICE}

Cuando Gaspar de Quiroga tomó posesión del arzobispado, el deán y los canónigos que formaban parte del cabildo eran:

DEÁN: Diego de Castilla

\section{CANONIGOS:}

Francisco Dávila (Arcediano de Toledo), Pedro González de Mendoza (tesorero), Miguel de Silva, Jerónimo Manrique, Jerónimo Mexía de Gomara, Licenciado Temiño, Alonso Delgado (maestrescuela), Rodrigo de Mendoza, Juan Manrique de Lara, Pedro de Carvajal, Luis de Luzón, Ramiro de Guzmán, Juan de la Cerda, Diego López de Quemada, Miguel Díaz, Fernando de Ribadeneira, Tomás de Borja, Rodrigo Tenorio, Gaspar de Mendoza, Antonio Zapata, Juan de Guzmán (abad de Santa Leocadia), Doctor Velásquez, Gaspar Yanes, Esteban Varela

García de Loaysa (arcediano de Guadalajara), Juan de Barrionuevo, Doctor Peralta, Diego de Guzmán, Licenciado Valdivieso, Doctor Barriovero, Pedro Velarde, Rodrigo Dávalos, Juan de Mendoza (arcediano de Talavera), Alonso

\footnotetext{
${ }^{61}$ AMAE, Santa Sede, leg. 21, fol. 86.

62 ACT, Actas capitulares, tomo 19, fols. 225v-226r, 228v, 241r.

$63 \mathrm{Ib}$., tomo 21, fols. $87 \mathrm{r}, 88 \mathrm{r}-\mathrm{v}$.
} 
Niño, Juan Calderón, Luis Dávalos, Bernardino de Sotomayor, y el Licenciado Ibarra.

Desde que Gaspar de Quiroga tomó posesión del arzobispado hasta su fallecimiento, los nombramientos que se realizaron fueron los siguientes:

\section{DEÁN:}

Juan de Mendoza: Tras la muerte de Diego de Castilla en 1584, fue nominado provisionalmente por espacio de dos meses para ocupar la dignidad de deán, pasando, posteriormente, en enero de 1585, a recibir nombramiento (ACT, Actas capitulares, tomo 18, fols. 88v, 105v, 130r).

Pedro de Carvajal: El 26 de enero de 1593, presentó al cabildo las bulas y letras apostólicas por las que se le nombraba en el deanato vaco por la muerte del Cardenal Juan de Mendoza (ib., tomo 21, fols. 10v-11v).

\section{CANÓNIGOS ORDINARIOS:}

Antonio Manrique: Presentó al cabildo la provisión de Gaspar de Quiroga el 2 de abril de 1578, pasando a cubrir la plaza vacante por renunciación que en manos del arzobispo hizo Juan de Guzmán. Tomó posesión el 20 de mayo del mismo año (ib., tomo 16, fols. 183v-184r, 201v).

Bernardino de Mendoza: Presentó al consistorio la provisión papal el 16 de mayo de 1578. Natural de Mondéjar, era clérigo de la diócesis de Toledo. Ocupó la canonjía y prebenda vaca por muerte de Diego de Guzmán, tomando la posesión el 7 de noviembre de dicho año. El 9 de septiembre, fue provisto capiscol por resignación «ex causa permutacionis» hecha por Pedro Velarde (ib., fols. 200r, 250r, 385r).

Juan Calderón: El 13 de mayo de 1579, hizo presentación al capítulo de la provisión realizada por Gaspar de Quiroga en una canonjía de penitenciario por la promoción de Jerónimo Manrique, su último poseedor, al obispado de Salamanca (ib., fols. 285v-286r).

Juan de Alarcón: Tomó posesión de la canonjía vaca por la muerte del doctor Peralta el 18 de agosto de 1579 (ib., fols. 301v-302r).

Francisco García de Valloboso: Hizo presentación al cabildo de la provisión para ocupar la canonjía que tuvo Miguel de Silva el 8 de octubre de 1579 (ib., fol. 311r).

Pedro de Quiroga: Sobrino del arzobispo, fue nombrado canónigo y tesorero en sustitución de Pedro González de Mendoza, presentando al cabildo la provisión realizada por su tío el 16 de noviembre de 1579. Era deán de la iglesia de León e inquisidor de Valladolid. Tomó posesión de sus cargos el 23 de diciembre de dicho año, prestando el juramento el 28 de septiembre de 
1580. El 23 de junio de 1584, fue promovido por su tío a obrero de la iglesia de Toledo, realizando el correspondiente juramento el 30 del mismo mes. Falleció unos días después.

Juan de Obregón: Presentó al cabildo la provisión hecha por Gaspar de Quiroga el 14 de diciembre de 1579. Era vicario general de la ciudad y arzobispado de Toledo. Ocupó la vacante producida por muerte de Ramiro de Guzmán, tomando posesión el 10 de febrero de 1580 (ib., fols. 334r-v).

Antonio Morejón: Ib., tomo 17, fol. 40v.

Antonio de Covarrubias: El 9 de septiembre de 1580, hizo presentación de las bulas papales para ocupar la maestrescolía y canonjía vaca por promoción de Alonso Delgado al obispado de Astorga. Perteneciente al Consejo Real, tomó posesión el 6 de octubre de 1580 (ib., tomo 18, fols. 389v-390r, 395r396r).

Pedro de Ayala: Efectuó la presentación al consistorio de la provisión realizada por el arzobispo el 24 de septiembre de 1580 para ocupar la plaza vacante por muerte de Gaspar de Mendoza. Era vicario del Coro de la iglesia de Toledo. Tomó posesión dos días después (ib., fols. 392r-393r).

Gabriel Suárez de Toledo: Presentó al cabildo la provisión hecha por Gaspar de Quiroga el 27 de septiembre de 1580 para ocupar la vacante producida por la resignación realizada por Pedro Velarde. Tomó posesión el 10 de noviembre (ib., fols. 393v, 407r-v).

Juan Bautista Pérez: El 7 de febrero de 1581, notificó al consistorio la provisión realizada por el arzobispo para cubrir la vacante producida por la muerte de Esteban de Varela. Natural de Valencia, precisó la licencia del rey a causa de no ser oriundo del reino, tomando la posesión el día 22 de abril. El 13 de febrero de 1585 Gaspar de Quiroga le otorgó el título de obrero de la catedral (ib., tomo 17, fols. 10r-v, 26r-v; ib., tomo 18, fol. 115v).

Gaspar de Quiroga: Sobrino del arzobispo, presentó al cabildo la provisión realizada por su tío el 26 de junio de 1581 para cubrir la vacante producida por la muerte de Juan de Barnuevo, tomando la posesión el 19 de julio (ib., vol.17, fols. 40v-41v, 47r-48r).

Juan de Llano de Valdés: Presentó al consistorio las bulas apostólicas que le otorgaban la canonjía el 27 de octubre de 1581. Perteneciente al Consejo de Inquisición, ocupó la prebenda resignada por el licenciado Temiño, también miembro de la Suprema, que había sido electo obispo de Ávila. Tomó posesión de la misma el 19 de enero de 1582 (ib., fols. 69v, 70v-73v, 76r, 88r).

Juan de Aramayona: Hizo presentación al cabildo de la provisión y colación hecha por Gaspar de Quiroga, el 2 de junio de 1582, para ocupar la canonjía y prebenda vaca por muerte de Juan de Llano de Valdés. Era inquisidor de 
Navarra. El 3 de octubre de 1583, el capítulo le señaló sepultura tras producirse su fallecimiento (ib., fols. 120r-121r, 132r-133r, 227v).

Andrés Fernández: El 3 de marzo de 1584, notificó al cabildo la provisión y colación realizada por el arzobispo para ocupar la vacante producida por muerte del doctor Aramayona. Era vicario general del arzobispado de Toledo. Tomó posesión el día 27 de dicho mes (ib., tomo 18, fols. 20r-21r, 27r28r).

Martín Alderete: Presentó al consistorio la provisión y colación hecha por Gaspar de Quiroga, el 10 de enero de 1585, para cubrir la vacante producida por la muerte de Pedro de Quiroga, tomando la posesión el 7 de marzo de dicho año (ib., fols. 106r-v, 122v-123r).

Francisco de Monsalve: Presentó al cabildo la provisión y colación realizada por el arzobispo el 5 de mayo de 1585, tomando posesión el día 10 de julio. Era deán de la iglesia de León (ib., fols. 143r-v, 167r-v).

Antonio Venegas de Figueroa: Al producirse la muerte del licenciado Ibarra, el arzobispo realizó la provisión de la canonjía, presentada al capítulo el 13 de septiembre de 1585, en favor del capiscol Bernardino de Mendoza, quien tomó posesión el día 16 de dicho mes. Sin embargo, el 28 del mismo, hizo resignación de ella en manos de Gaspar de Quiroga, que la proveyó en Antonio Venegas de Figueroa, quien efectuó el acto de posesión del 17 de enero de 1586 (ib., fols. 179v-180v, 182v-183v, 209r-v).

García de Mendoza y de la Cerda: El 3 de abril de 1587, presentó al cabildo la provisión y colación realizada por Quiroga como capiscol y canónigo en las vacantes provocadas por la muerte de Bernardino de Mendoza (ib., vol.19, fols. 18v-19r).

Juan de Zúñiga: Perteneciente al Consejo de Inquisición, el 31 de octubre de 1587, presentó al consistorio las bulas y letras apostólicas que le proveían como canónigo, tomando posesión el 17 de diciembre. El 4 de enero de 1588, se ordenó al cabildo que le tuviesen por presente como al resto de los canónigos pertenecientes a la Suprema (ib., fols. 68v-69r, 74r-75r, 77v).

Juan de Quiroga: El 18 de enero de 1588, presentó al consistorio la provisión y colación otorgada por el arzobispo para ocupar la canonjía vacante por la muerte de Luis Dávalos, de la que tomó posesión el 19 de febrero (ib., fols. 81r, 82r).

Gregorio Bravo de Sotomayor: Perteneciente al Consejo Real y auditor del Tribunal de la Sacra Rota, hizo presentación al cabildo, el 7 de abril de 1588 , de la provisión y colación hecha por el arzobispo para cubrir el canonicato y prebenda vaca por omisión y privación de don García de Mendoza. Tomó posesión el 23 de junio (ib., fols. 100r, 116v-117r). 
Alonso Serrano: El 28 de septiembre de 1588, hizo presentación al capítulo de la provisión y colación realizada por Quiroga, por la que quedaba proveído en la canonjía y prebenda vaca por el fallecimiento del doctor Obregón. Tomó posesión el 31 de octubre (ib., fols. 137r-v, 144r-v).

Ginés de Soto: Clérigo presbítero del arzobispado de Toledo, presentó al cabildo, el 22 de septiembre de 1589, las bulas y letras apostólicas de coadjutoría y regreso del papa Pío IV, fechadas el 5 de septiembre de 1560, por las que quedaba proveído en la canonjía que poseía Rodrigo de Mendoza con título de coadjutor con futura sucesión. Tomó posesión el 13 de noviembre (ib., fols. 225v-226r, 241r-v).

Álvaro de Monsalve: El 22 de septiembre de 1589, hizo presentación al consistorio de la provisión y colación realizada por el arzobispo, por la que le proveía en la canonjía vaca por muerte de Juan Manrique, tomando la posesión el 11 de noviembre (ib., fols. 226r-v, 240v-241r).

Francisco Morejón: Ocupó la canonjía vacante por el fallecimiento de Pedro de Ayala, presentando al cabildo la provisión y colación otorgada por Quiroga el 8 de octubre de 1589. Tomó la posesión el 13 de noviembre (ib., fols. 231r-v, 242r-v). También ostentó el cargo de vicario del Coro que había poseído Pedro de Ayala (ib., fols. 253r, 254r-v; ib., tomo 20, fol. 1r).

Miguel de Salazar: El 29 de marzo de 1590, presentó al consistorio unas bulas y letras apostólicas por las que era proveído coadjutor «ad futuram succesionem» en la canonjía que poseía Miguel Díaz (Ibid., fols. 22r-v, 24r). Por motivo del pleito que se mantuvo sobre dicha provisión, tomó posesión el 28 de febrero de 1592, sucediéndole en el cargo el otro litigante, Alonso Gómez (ib., fols. 206v, 207r, 217v-218r).

Gabriel Ortiz de Sotomayor: Clérigo de Toledo, el 19 de diciembre de 1590, hizo presentación al cabildo de la provisión y colación hecha por Quiroga, por la que era proveído en la canonjía vaca por muerte de Gregorio Bravo. Tomó posesión en abril de 1591 (ib., fols. 96r, 126v-127v).

Francisco Ruiz de Velasco: En enero de 1591, hizo presentación al consistorio de la provisión y colación realizada por el arzobispo, por la que era proveído para la canonjía vacante por muerte de Juan de la Cerda. Tomó posesión el 8 de octubre (ib., fols. 98v-99r, 179r).

Francisco de Espinosa: El 18 de mayo de 1591, presentó al capítulo la provisión y colación hecha por el arzobispo, por la que era proveído en la canonjía y prebenda de la penitencia vaca por el fallecimiento del doctor Juan Calderón. Tomó posesión el 1 de junio (ib., fols. 139v, 144v-145r).

Antonio Cordones: Quiroga escuchó la petición que el cabildo realizó para que Antonio Cordones fuese proveído en la canonjía vaca por la muerte de 
su tío, el tesorero Francisco García de Valloboso. El 15 de julio de 1591, presentaba la provisión y colación realizada por el prelado, tomando posesión el 30 de dicho mes. Así mismo, se exoneró de su oficio de contador (ib., fols. 153v-154r, 156r-v, 159r, 161r-v).

Jerónimo Pacheco: El 7 de enero de 1592, hizo presentación al cabildo de la colación y provisión realizada por el prelado para ocupar la canonjía vacante por muerte del licenciado Juan Bautista Vélez (ib., fol. 196r).

Gabriel Pacheco: Hermano del marqués de Villena, el 12 de febrero de 1592, presentó al consistorio la colación hecha por Quiroga para ocupar la canonjía vaca por el fallecimiento del cardenal Juan de Mendoza. Tomó posesión el 20 de abril (ib., fols. 210r, 230v-231r). El 14 de julio de 1593, notificó al capítulo las bulas y letras apostólicas por las que era proveído en el canonicato y prebenda vaca por la muerte del licenciado Bautista Vélez, que había sido otorgado por Quiroga a Jerónimo Pacheco, que resignó el mismo en manos del pontífice. Tomó posesión al día siguiente (ib., tomo 21, fols. 54r55r). Así mismo, el 15 de diciembre, hizo presentación al cabildo de la provisión realizada por Gaspar de Quiroga, por la que le proveía en la canonjía y prebenda vacante por el fallecimiento del licenciado Andrés Hernández. Tomó posesión el día 30 de dicho mes (ib., fol. 99v, 105r-v). El 15 de marzo de 1594, presentó al cabildo el nombramiento de capiscol realizado por el arzobispo, cargo que se hallaba vacante por la promoción de Gaspar de Quiroga al arcedianato de Talavera (ib., fol. 122r).

Francisco de Arganda: Inquisidor en el tribunal de Cuenca, el 13 de abril de 1592, notificó al capítulo las bulas apostólicas que le proveían en el canonicato y prebenda vaca por resignación hecha en manos del pontífice por Juan Bautista Pérez, electo obispo de Segorve. Tomó posesión el 24 de septiembre (ib., tomo 20, fols. 227r-v, 267r-268r).

Jerónimo de Miranda Vivero: El 15 de julio de 1593, hizo presentación al consistorio de las bulas y letras apostólicas por las que era proveído en el canonicato y prebenda que vacaron por la muerte de Juan de Mendoza. Tomó posesión el 20 de diciembre (ib., tomo 21, fols. 55r-v, 99v-103r).

Pedro Deza: Sobrino del Cardenal Deza, el 21 de febrero de 1594, puso en conocimiento del cabildo la provisión realizada por Gaspar de Quiroga para que ocupase el canonicato y prebenda vaca por el fallecimiento de Antonio Manrique. Tomó posesión dos días después (ib., fol. 117v).

Antonio Canseco de Quiñones: El 27 de junio de 1594, presentó al capítulo la provisión y colación hecha por el arzobispo, por la que le proveía en la canonjía vaca por promoción de Gabriel Pacheco a otra canonjía de esta iglesia. Tomó posesión el 14 de noviembre (ib., fols. 144r-v, 176v). 


\section{Canónigos doctorales}

Doctor Alonso Hondegardo: Ocupó la canonjía doctoral vaca por la muerte del licenciado Valdivieso. Tomó posesión de la misma el 28 de enero de 1578 (ib., tomo 16, fols. 169r-v).

Diego de Virviesca: Habiendo resignado el día anterior en manos de Gaspar de Quiroga su capellanía de los Reyes Nuevos, el 2 de marzo de 1581, fue elegido para ocupar la plaza de Diego López de Quemada, fallecido, tomando la posesión el 4 de abril del mismo año (ib., tomo 17, fols. 15r-v, 23r-v).

Doctor Salvador Navarro: Tras la muerte del Doctor Hondegardo, comunicada al cabildo el 3 de enero de 1583, se procedió a su elección el día 21 de dicho mes, tomando posesión el 22 de agosto (ib., fols. $165 \mathrm{v}, 179 \mathrm{v}-180 \mathrm{v}$, 218r-v).

Alonso Anaya de Pereira: El 22 de marzo de 1583, fue realizada por Gaspar de Quiroga la provisión del canonicato y prebenda doctoral vaca por muerte de Fernando de Ribadeneira. Tomó posesión de la misma el 25 de mayo (ib., fols. 180v, 196v).

Juan Pérez de Valenzuela: El 12 de noviembre de 1594, fue elegido para ocupar la canonjía doctoral vacante por la muerte del doctor Navarro (ib., tomo 21 , fols. $174 \mathrm{v}-176 \mathrm{r})$.

\section{Canónigos magistrales}

Alonso de Mendoza: Al producirse la muerte del doctor Barriovero, comunicada al cabildo el 4 de diciembre de 1577, fue elegido para cubrir su plaza en febrero de 1578. Era chantre de Alcalá, y tomó la posesión el 23 de julio de dicho año. El 17 de septiembre de 1580, presentó al consistorio la provisión hecha por Gaspar de Quiroga para la abadía de San Vicente de la Sierra, tras la resignación hecha en manos del arzobispo por Andrés Pacheco. Tomó posesión dos días después (ib., tomo 16, fols. 145r, 173r-174r, 219r, 390r$391 v)$.

Gabriel de Cárdenas: Vacante la canonjía magistral de Sagrada Escritura por la promoción del doctor Velázquez al obispado de Osma, fue elegido para ocupar esta plaza el 23 de febrero de 1579, tomando la posesión el 6 de abril (ib., fols. 251r, 267r-269r, 279r-v).

Matías Rodríguez: El 29 de febrero de 1592, fue elegido para ocupar la canonjía vacante por la muerte de Gabriel de Cárdenas (ib., tomo 20, fols. 218v$219 v$ ). No tomó posesión hasta el 13 de junio, existiendo algunas dificultades, porque el prelado pretendía tener derecho a su provisión (ib., fols. 237r-238r, 244r-v). 
Pedro de Castro: Canónigo magistral de Ávila, el 12 de septiembre de 1594, fue elegido para ocupar la canonjía vaca por la muerte del doctor Matías Rodríguez. Tomó posesión el 20 de octubre (ib., tomo 21 , fols. $157 \mathrm{v}-158 \mathrm{v}$, $158 \mathrm{v}-169 \mathrm{r})$.

\section{CANÓNIGOS EXTRAVAGANTES:}

Lope Sánchez: El 7 de julio de 1578, presentó al cabildo la provisión realizada por el arzobispo para cubrir la vacante producida por muerte de Benito Villalpando, tomando la posesión el día 21 del mismo mes (ib., tomo 16, fols., $221 \mathrm{v}, 213 \mathrm{r}, 217 \mathrm{v})$.

Busto de Manzanos: Clérigo de Toledo, realizó la presentación de la provisión arzobispal el 7 de septiembre de 1579 (ib., fol. 305r).

Mancio de Villafaña: Clérigo cura de Santorcaz, presentó la provisión realizada por Gaspar de Quiroga el 11 de abril de 1580 (ib., fols. 361v-363r).

Juan Ortiz de la Torre: Presentó al cabildo la provisión arzobispal para cubrir la vacante producida por muerte de Alonso Pérez el 5 de noviembre de 1580 (ib., fol. 404v).

Alonso del Aguila: Tras la resignación realizada por Gaspar Xuárez, dicho clérigo hizo presentación en el consistorio de la provisión realizada por Gaspar de Quiroga el 18 de febrero de 1581 (ib., tomo 17, fols. 12v, 13v).

Pedro de Illescas: Presentó al cabildo la provisión y colación realizada por el arzobispo el 13 de julio de 1582, por la que se le nombraba para cubrir la plaza vacante producida por la muerte de Juan de Villarreal (ib., fols. 129r, 130r).

Cristóbal de Olmos: El 2 de junio de 1583, notificó al cabildo la provisión arzobispal para cubrir la vacante producida por la resignación hecha por Damián de Torres. Tomó posesión cuatro días después (ib., fols. 199r, 200v).

Juan Sánchez: Dicho clérigo notificó al capítulo la provisión y colación realizada por Gaspar de Quiroga el 30 de agosto de 1583 para cubrir la plaza vaca por la resignación efectuada por el licenciado Meneses de Avendaño (ib., fols. 220r, 235v).

Gregorio López: El 17 de mayo de 1586, presentó al cabildo el nombramiento realizado por el pontífice para ocupar la vacante producida por la resignación que en manos del papa había hecho Juan Gómez (ib., tomo 18, fols. $243 \mathrm{v}, 245 \mathrm{v}-246 \mathrm{r}$ ).

Francisco de Benavente: El 22 de septiembre de 1587, presentó al cabildo la provisión y colación hecha por Quiroga para que ocupase la canonjía extravagante vaca por muerte de Jerónimo de Barreda (ib., tomo 19, fols. 59v$60 \mathrm{v})$. 
Juan de Madrid: Hizo presentación al consistorio de la colación y provisión realizada por al arzobispo el 20 de diciembre de 1591, por la que le proveía en la vacante producida por el fallecimiento de Juan de Ortiz. Tomó posesión el 10 de enero de 1592 (ib., tomo 20, fols. 194v, 198r-v).

Pedro de Villarreal: El 6 de noviembre de 1592, notificó al cabildo la provisión y colación realizada por Quiroga, por la que era proveído en la canonjía extravagante vaca por muerte del bachiller Eugenio López. Tomó posesión el día 9 de dicho mes (ib., fols. 276r, 277r).

Francisco Mexía: Presentó al capítulo la provisión y colación efectuada por el arzobispo el 29 de mayo de 1593, por la que era proveído en la canonjía extravagante vaca por resignación simple que en manos del prelado hizo Lope Sánchez Gallo, tomando posesión el 1 de junio (ib., tomo 21, fols. 42r-43r).

Domingo de Alvear: El 25 de junio de 1593, hizo presentación al consistorio de la colación y provisión hecha por Quiroga, por la que era proveído en el canonicato extravagante que había vacado por el fallecimiento de Melchor de Santa Cruz. Tomó posesión el 9 de julio (ib., fols. 50v, 52r-v).

Alonso Muñoz: Notificó al capítulo la provisión realizada por el arzobispo el 17 de diciembre de 1593, por la que era proveído en el canonicato extravagante vacante por la muerte de Pedro de Acebedo. Tomó posesión dos días después (ib., fols. 100r, 103v, 104v).

Juan Corral: El 27 de julio de 1594, hizo presentación al cabildo de la colación y provisión realizada por Quiroga, por la que le proveía en la canonjía extravagante vaca por la promoción de Alonso Muñoz a una capellanía del Coro. Tomó posesión el 29 de julio (ib., fol. 148v).

\section{RACIONEROS:}

Antonio Fernández: Natural de Astorga, el 20 de diciembre de 1577, se le dió posesión de la ración vaca por muerte de Melchor de la Fuente (ib., tomo 16, fol. 149v).

Alonso del Campo: El racionero Alonso del Campo fue nombrado secretario del cabildo el 4 de marzo de 1578 (ib., fol. 178v).

Francisco López: Tiple natural de Madrid, fue presentado por el arzobispo el 2 de abril de 1578 para ocupar la ración vaca por muerte de Lucas Sánchez. Tomó posesión de la misma el día 16 de dicho mes (ib., fols. 182v-183r, 190v).

Juan de Guimaranes: Teniendo posesión de la ración, el 26 de mayo de 1578, solicitó al cabildo que se le tuviese por presente en dicha iglesia aduciendo que había entrado al servicio del arzobispo. Su petición fue denegada (ib., fols. 202v-203r). 
Juan Muñoz: Presentado por el pontífice, el 17 de junio de 1578, para ocupar la ración vaca por muerte de Cristóbal Collantes, obtuvo el nombramiento el 20 de marzo de 1579 (ib., fols. 208v, 372v).

Bachiller Nicolás Galindo: Se le otorgó la ración sujeta al oficio de capiscol el 4 de julio de 1578 (Ibid., fol. 211r). El 26 de noviembre de 1585, recibió provisión de una ración, vaca por muerte de Juan de Rincón, que estaba unida al oficio de sochantre (ib., tomo 18, fols. 196v-197r).

Antonio Cordones: Vecino de Tembleque, fue presentado por el pontífice el 18 de abril de 1579 para ocupar la ración vaca por muerte de Diego Alonso Silicio. Primeramente, el papa había hecho merced de la misma a Francisco García de Valonoso, tío de Antonio Cordones, que renunció en favor de su sobrino (ib., tomo 16, fol.281v).

Pedro Chacón: El 26 de junio de 1579, hizo presentación al cabildo de la provisión de la ración concedida por el pontífice Gregorio XIII (ib., fol. 292v).

Melchor Sánchez: Clérigo natural de Tarancón, diócesis de Cuenca, fue presentado al cargo de racionero por Gaspar de Quiroga el 27 de agosto de 1579 (ib., fol. 304r).

Lorenzo Serrano: Fue presentado por el arzobispo para ocupar la ración vaca por muerte de Tomás Pinel el 10 de noviembre de 1579 (ib., fol. 320r).

Alonso Serrano: Perteneciente al Consejo de la Dignidad, fue provisto por Gaspar de Quiroga, el 23 de noviembre de 1579, para cubrir la ración vaca por muerte de Hernando de Lunar (ib., fol. 328r).

Jerónimo de Peraza: El 27 de noviembre de 1579, se le otorgó una ración de órgano, de la que tomó posesión el 21 de marzo de 1580 (ib., fols. 330r, $357 \mathrm{v})$.

Bernardino de Barrionuevo: El 10 de diciembre de 1579, recibió nombramiento del arzobispo para ocupar la ración vacante por muerte de Alonso del Campo, tomando la posesión el 18 de enero de 1580 (ib., fols. 331v, 345r-v).

Gabriel Rosete Villacampa: La provisión como racionero aparece fechada el 7 de marzo de 1580 (ib., fol. 356r).

Juan de Amocibar: Tomó posesión de la ración el 11 de abril de 1580 (ib., fols. 361r-v).

Dionisio Ruiz de la Peña: Familiar de Gaspar de Quiroga, obtuvo el favor arzobispal para ocupar la ración vaca por muerte de Francisco Laredo el 3 de octubre de 1580 (ib., fol. 394v).

Ginés de Boluda: El 7 de diciembre de 1580, obtuvo la provisión de Gaspar de Quiroga para ocupar el oficio de maestro mayor de capilla y de una ración vaca por muerte de Andrés de Torrentes (ib., fols. 412v, 415r). 
Agustín de Mena: Contralto, obtuvo la provisión arzobispal para cubrir la vacante producida por muerte de Francisco Valdivieso el 23 de diciembre de 1580 (ib., fol. 415v; ib., tomo17, fols. 3r-v, 17r).

Lemes de Gomara: Tomó posesión de la ración el 23 de diciembre de 1580 (ib., tomo 16, fol. 415v).

Pedro de Río: El 5 de enero de 1581, fue presentado por Gaspar de Quiroga para ocupar la ración vaca por muerte de Joaquín de Aguilera, tomando posesión de la misma el 14 de febrero (ib., tomo 17, fols. 3v-4r, 11r-v).

Mateo Cabello: Tomó posesión de la ración el 25 de enero de 1581 (ib., fols. 7r-v).

Jorge de Santamaría: El 13 de abril de 1581, fue presentado por el arzobispo para ocupar la ración vacante por la resignación realizada por Lorenzo Serrano. El cabildo cometió a Rodrigo Dávalos que agradeciese en nombre del mismo al prelado esta merced (ib., fol. 23v).

Jerónimo Serrano: El 14 de agosto de 1581, presentó al consistorio las bulas apostólicas por las que era proveído en la ración vaca por la resignación efectuada por el licenciado Serrano. Tomó posesión de la misma el 5 de septiembre (ib., fols. 53r, 58v).

Gómez de Mendoza: Hizo presentación al cabildo de las bulas apostólicas por las que era proveído en una ración el 19 de agosto de 1581, tomando la posesión el 27 de octubre (ib., fols. 69v-70r).

Francisco de Tapia: El 7 de mayo de 1582, presentó al cabildo la provisión realizada por Gaspar de Quiroga para ocupar la vacante producida por la resignación hecha por el licenciado Dionisio Ruiz de la Peña. Tomó posesión el día 26 del mismo mes (ib., fols. 110v, 112r, 116v-117r).

Alonso Sáez de Carvajal: El 26 de enero de 1583, notificó al capítulo la provisión arzobispal para cubrir la ración vaca por muerte de Pedro Gaytán (ib., fols. 170r-v, 189v-190r).

Andrés de Valdivieso: El 18 de febrero de 1583, presentó las bulas apostólicas por las que era proveído en la ración vaca por resignación hecha en manos del papa por Juan de Medina, tomando la posesión el 31 de marzo (ib., fols. 174r-v, 183v).

Francisco Crespo: El 3 de septiembre de 1583, hizo presentación de las bulas apostólicas que le proveían en la ración de la que hizo resignación Julián Crespo en manos del papa. Tomó posesión el día 19 de dicho mes (ib., fols. $221 \mathrm{v}, 223 \mathrm{v}-224 \mathrm{r})$.

Francisco de Guzmán: El 4 de agosto de 1584, realizó la presentación al cabildo de la provisión arzobispal para ocupar la ración vacante por la muerte del maestro Damián Cedillo (ib., tomo 18, fols. 64v-65r, 75r-v). 
Bernardino Pérez: El 4 de noviembre de 1585, notificó al cabildo la provisión realizada por el pontífice para ocupar la ración vaca por la resignación hecha por Martín Pérez en manos del papa. Tomó posesión el día 19 del mismo mes (ib., fols. 190v-191r, 194v).

Licenciado Francisco Lezcano: El 6 de noviembre de 1585, presentó la provisión realizada por Gaspar de Quiroga para cubrir la ración vaca por la muerte de Andrés de Valdivieso (ib., fol. 191v).

Doctor Jerónimo Buxeda de Leyva: Hizo presentación al cabildo de la provisión hecha por Gaspar de Quiroga el 20 de diciembre de 1585. Pasó a ocupar la vacante producida por la resignación realizada por Bernardino de Barnuevo «causa permutationis» por la tesorería de la iglesia de Soria, diócesis de Osma. Tomó la posesión el 4 de marzo de 1586 (ib., fols. 201r, 220v221r).

Martín de San Pedro: El 7 de abril de 1586, notificó al consistorio la provisión arzobispal para ocupar la ración vaca por muerte de Juan de Guimaranes (ib., fols.227r, 228r, 230v).

Gonzalo Martínez: El cabildo le proveyó en el oficio de socapiscol y la ración unida al mismo vacante por la promoción de Nicolás Galindo el 7 de mayo de 1586. Fue además sochantre (ib., fols.237v, 245v).

Simón de Carranza: El 31 de enero de 1587, se presentó la provisión y colación realizada por Quiroga para la ración vaca por la muerte de Cristóbal de Verrío al licenciado Simón de Carranza, de la diócesis de Calahorra y fiscal del tribunal inquisitorial de Zaragoza. Tomó posesión el 21 de marzo (ib., tomo 19 , fols. 8r-9r, 17r-v).

Gaspar Martínez: Clérigo natural del reino de Valencia, el 4 de marzo de 1587, presentó al cabildo la provisión y colación realizada por el arzobispo. Cubrió la vacante producida por la muerte del licenciado Francisco Lezcano. Tomó posesión el 16 de abril (ib., fols. 13v-14r, 23v-24r, 25v).

Martín de Herrera: El 8 de abril de 1587, se informó al consistorio de la provisión y colación realizada por Quiroga. Ocupó la plaza del fallecido Alonso Sánchez, de la que tomó posesión dos días después (ib., fols. 20r, 21v-22r).

Esteban Primo: Clérigo de la diócesis de Palencia, ocupó la ración vaca por muerte de Francisco Correas. El 6 de octubre de 1587, presentó al cabildo la provisión y colación hecha por Quiroga, tomando posesión el 3 de noviembre (ib., fols. 63v, 64r-v, 68v). Poco después, hizo resignación de dicha ración en manos del arzobispo, a la que volvió a acceder por la provisión que nuevamente hizo Quiroga, que fue presentada al consistorio el 15 de marzo de 1589, tomando posesión al día siguiente (ib., fols. 175v, 177r-v). Unos meses más tarde, volvió a hacer resignación de la misma en manos del papa, 
obteniendo el nombramiento para ocupar otra vacante el 5 de octubre de 1589 , por la provisión y colación que de nuevo le otorgó Quiroga (ib., fols. 228r, 229v-230r).

Gabriel de Ocampo: Por resignación que Martín de Herrera hizo en manos del arzobispo, este proveyó la vacante en Gabriel de Ocampo, que presentó al consistorio la provisión y colación el 11 de enero de 1588, tomando posesión el 26 de febrero (ib., fols. 79r, 84v, 91v-92r).

Baltasar de Avilés: El 10 de febrero de 1588, notificó al cabildo las letras apostólicas por las que se le nombraba para ocupar la ración que poseía Juan López de Aranda, que vacó «causa permutationis» de ciertos préstamos en el obispado de Pamplona. Tomó sesión el 11 de abril (ib., fols. 87r-v, 103v104r).

Juan de Gaa Aliende: El 18 de julio de 1588, hizo presentación al consistorio de las bulas y letras apostólicas que le proveían en la ración vaca por resignación hecha en manos del papa por Juan Muñoz. Tomó posesión el 3 de agosto (ib., fols. 120r, 126r-v).

Martín de Tejada: Racionero de Calahorra, el 27 de julio de 1588, obtuvo la provisión del cabildo para cubrir la vacante producida por la dejación realizada por Martín de Herrera (ib., fols. 124v-125r).

Antonio de Tavares: Clérigo de la diócesis de Palencia, el 9 de noviembre de 1588 , presentó al consistorio las bulas y letras apostólicas para ocupar la ración vaca por resignación realizada por Dionisio Ruiz de la Peña en manos del pontífice. Tomó posesión el 21 de enero de 1589 (ib., fols. 146r, 148r, $160 \mathrm{v}-161 \mathrm{r})$.

Juan Ruiz de Hamusco: Clérigo, el 18 de febrero de 1589, hizo presentación al consistorio de las bulas y letras apostólicas por las que quedaba proveído en la ración que poseía Gabriel de Ocampo, vaca «causa permutationis» a un préstamo de Santa María de la Varga y otro en San Juan de Uceda, ambos en la diócesis de Toledo. Tomó posesión el 22 de marzo (ib., fols. 167v, 169r, 181v).

Alonso de Marinas: Clérigo, el 3 de julio de 1589, presentó al cabildo la provisión y colación hecha por el arzobispo, por la que le proveía en la ración vaca por muerte de Francisco Crespo. Tomó posesión el 26 de agosto (ib., fols. 207v, 219v, 220r).

Luis Primo: Clérigo de la diócesis de Palencia, el 25 de septiembre de 1589, notificó al consistorio las bulas y letras apostólicas por las que era proveído en la ración vaca por la resignación hecha por Esteban Primo en manos del papa. Tomó posesión el 27 de octubre (ib., fols. 227v-228v, 235v-236r).

Juan Alonso: El 31 de enero de 1590, presentó al cabildo la provisión y colación hecha por Quiroga, por la que le proveía en la ración vaca por la muer- 
te de Luis Niño. Tomó posesión el 10 de febrero (ib., tomo 20, fols. 7v, 10v11r).

Hernando y Marcelo Segura: Fueron proveídos por el consistorio en dos raciones anexas el 28 de febrero de 1590, que se hallaban vacantes por los fallecimientos de Miguel de Recalde y Hernando Navarro. Estas designaciones fueron posteriormente ratificadas por las provisiones y colaciones hechas por Quiroga. Tomaron posesión el 17 de abril (ib., fols. 15r-16r, 17r$18 \mathrm{r}, 35 \mathrm{v}-38 \mathrm{v})$.

Andrés García: Presentó al cabildo la provisión y colación realizada por el arzobispo el 23 de noviembre de 1590, para ocupar la ración vaca por muerte de Juan de Horozco. Tomó posesión el 14 de diciembre (ib., fols. 89v, 94r-v).

Miguel González: Clérigo presbítero, era natural de Siete Iglesias. El 23 de noviembre de 1590, presentó al capítulo la provisión y colación hecha por Quiroga, por la que le proveía en la ración vaca por muerte de Alonso de Carvajal. Tomó posesión el 17 de diciembre (ib., fols. 90r, 95v, 97r-v).

Andrés Guio de Llanos: Clérigo vecino de Toledo, el 27 de diciembre de 1590, hizo presentación al consistorio de las bulas y letras apostólicas por las que era nombrado racionero en la vacante producida por la muerte de Pedro Ortiz. Tomó posesión el 30 de enero de 1591 (ib., fols. 98r, 105v-106r).

Andrés Mendo: El 24 de agosto de 1591, presentó al cabildo la provisión y colación realizada por el arzobispo, por la que le proveía en la ración vaca por el fallecimiento de Alonso López de Salcedo. Tomó posesión el 10 de octubre (ib., fols. 166r, 179v-180r).

Sebastián Mudarra: La promoción al canonicato de Antonio Cordones dejó vaca una ración que fue proveída por Quiroga en Sebastián de Mudarra, que hizo presentación al cabildo de la provisión y colación correspondiente el 24 de agosto de 1591. Tomó posesión el 13 de abril de 1592 (ib., fols. 166r-v, $227 \mathrm{v}-228 \mathrm{r})$.

Juan Rodríguez: Clérigo de Grados de la diócesis de Cuenca, el 26 de agosto de 1591, presentó al cabildo las bulas y letras apostólicas que le proveían en la ración vacante por la resignación realizada por Melchor Sánchez en manos del pontífice. Tomó posesión el 13 de septiembre (ib., fols. 168r, 172v173r).

Juan Martínez: Clérigo presbítero del arzobispado de Toledo, el 18 de octubre de 1591, notificaba al consistorio las bulas y letras apostólicas por las que era proveído en la ración que resignó en manos del papa Alonso López de Salcedo. Tomó posesión el día 31 de dicho mes (ib., fols. 181v, 184r-v).

Luis Honguero: El 26 de febrero de 1592, el cabildo le proveyó en la ración que había dejado vacante Martín de Iglesias (ib., fol. 216r). 
Francisco de Quiroga: El 23 de marzo de 1592, presentó al consistorio la colación realizada por el arzobispo, por la que le proveía en la ración vaca por muerte de Bartolomé Quevedo. Tomó posesión el 13 de julio (ib., fols. 224r, 250v-251r).

Francisco Ortega: Clérigo presbítero de la diócesis de Toledo, el 25 de abril de 1592, hizo presentación al capítulo de la provisión y colación hecha por Quiroga, por la que le proveía en la ración vaca por el fallecimiento de Juan de Amocibar. Tomó posesión el 2 de mayo (ib., fols. 233r, 234v-235r).

Gonzalo Martínez: Socapiscol el 3 de junio de 1592, pidió al cabildo que, atendiendo a sus treinta y dos años de servicio, le hiciesen la merced de proveerle en la ración de sochantre vaca por muerte del racionero Nicolás Galindo. Su solicitud fue atendida, tomando posesión el 6 de junio (ib., fols. 240v, 242r-v).

Leandro de Segura: Clérigo de Corona de la diócesis de Palencia, el 11 de septiembre de 1592, el consistorio solicitó a Quiroga que fuese proveído en la ración vaca por el fallecimiento de Martín de Iglesias. Atendida la petición, el prelado otorgó la provisión y colación pertinente, tomando posesión el 14 de noviembre (ib., fols. 264v, 266r-v, 277v-278r).

Miguel Echay de Ripa: Tomó posesión de la ración que había poseído Antonio Tavares el 12 de octubre de 1592 (ib., fols. 270v-271r).

Cebrián Muñoz: El 23 de noviembre de 1592, presentó la provisión y colación realizada por Quiroga, por la que quedaba proveído en la ración vaca por la muerte del licenciado Simón de Carranza. Tomó posesión el 14 de enero de 1593 (ib., fol. 279v; ib., Vol.21, fol. 7r-v).

Tomás de Miranda: Habiendo presentado, el 11 de febrero de 1593, la dispensación apostólica «super defectus natalium», que le habilitaba para poder ostentar beneficios eclesiásticos, el consistorio le nombró en la ración vaca por muerte de Marcelo Segura. Unos días después, el prelado despachaba la pertinente colación, tomando posesión el 13 de abril (ib., fols. 16v, 17v-18r, 29v, 30r).

Alonso Lobo: Canónigo de Osma y residente en Sevilla, el 22 de septiembre de 1593, el cabildo le dió provisión de la ración y oficio de maestro de capilla, que se encontraba vaco por dejación de Ginés de Boluda. Días después, obtuvo la correspondiente colación realizada por Gaspar de Quiroga. Tomó posesión el 7 de diciembre (ib., fols. 74v, 79v, 95r, 97r-v).

Antonio Sancho: Natural de Tauste, en el reino de Aragón, el capítulo le nominó en una ración de socapiscol vacante por la dejación realizada por Gonzalo Martínez (ib., fol. 92r).

Juan de Ricobayo: Secretario del tribunal inquisitorial de Toledo, notificó al cabildo, el 11 de diciembre de 1593, las bulas y letras apostólicas por las que 
era proveído en la ración de que hizo resignación Francisco de Quiroga «causa permutationis» por ciertos beneficios en el obispado de Oviedo. Tomó posesión el 22 de enero de 1594 (ib., fols. 98v, 11v-112r, 115v).

Alonso Gómez Cabezón: El 29 de abril de 1594, presentó al consistorio las bulas y letras apostólicas por las que era proveído en la ración que tuvo Gómez de Mendoza, de la que hizo resignación «causa permutationis» por el curato de Pulgar, de la diócesis de Toledo (ib., fol. 133v).

Pedro Beltrán: Clérigo presbítero de la diócesis de Pamplona, notificó al cabildo, el 23 de junio de 1594, la bula y letras apostólicas por las que era proveído racionero en la vacante producida por resignación de Fernando Samaniego «causa permutationis» por dos préstamos que Pedro Beltrán poseía en la diócesis de Pamplona. Tomó posesión el 29 de julio (ib., fols. 143r, 149r-v).

Lucas Cabello: El 20 de octubre, presentó al capítulo la colación y provisión realizada por Quiroga para que ocupase la ración que había poseído Cebrián Muñoz de Vizcaya, de la que hizo dejación «causa permutationis» por un beneficio simple en la parroquia de Illana (ib., fol. 169r).

\section{CAPELLANES:}

Cristóbal de Espinosa: Natural de Santa Gadea y clérigo en la diócesis de Burgos, fue proveído en una capellanía de D.Pedro González de Mendoza el 30 de abril de 1578 (ib., tomo 16, fol. 197v).

Francisco López: Racionero, el 2 de junio de 1578, le fue concedida por el maestrescuela una capellanía de Juan Ruiz de Ribera vaca por la muerte de su anterior poseedor (ib., fol. 303v).

Licenciado Merino: Juan de Barnuevo como semanero le nominó para una capellanía de Sacedo vaca por muerte de Alonso Ortiz el 6 de junio de 1578. Era natural de Cazorla y residente en Toledo (ib., fol. 204v).

Juan Bautista de Zárate: El 7 de junio de 1578, Juan de Barnuevo como semanero le nombró para ocupar una capellanía de Gutiérrez Díaz vaca por muerte de Benito Villalpando. Era clérigo presbítero (ib., fol. 205r). El 9 de julio del mismo año, presentó al cabildo una provisión arzobispal para que se le diese la posesión de la capellanía vacante por fallecimiento de Juan de Benavente (ib., fols. 212r, 214r).

Alonso Díaz: Criado de Juan de Mendoza, fue elegido por Juan de Barnuevo como semanero para ocupar una capellanía de Pedro Tenorio vaca por muerte de Benito Villalpando el 9 de junio de 1578 (ib., fols. 205r, 206r).

Diego de Estrada: El 12 de junio de 1578, fue nombrado capellán de San Pedro para cubrir la vacante producida por la muerte de Juan de Benavente (ib., fol. 207r). Licenciado Alonso Rodríguez y Bachiller Aguilar: Sobrino 
del racionero Caballero, fue nombrado junto al bachiller Aguilar para ocupar dos capellanías erigidas de nuevo por D. Alonso de Rojas el 9 de julio de 1578 (ib., fol. 213r).

Miguel del Barco: El 18 de agosto de 1578, presentó al cabildo la provisión papal para ocupar la capellanía vaca por muerte de Pedro Tamayo (ib., fol. 225v).

Pedro de Cabañas: El 25 de septiembre de 1578, hizo presentación al consistorio de la provisión pontificia para ocupar la capellanía vacante por la resignación realizada por Antonio de Heredia, tomando posesión el 27 de octubre (ib., fols. 241v, 242v, 245v).

Martín de San Pedro: Provisto en una capellanía de Pedro González de Mendoza el 19 de noviembre de 1578 (ib., fol. 252r).

Juan de Aguirre: Provisto en una capellanía de Pedro González de Mendoza el 10 de diciembre de 1578 (ib., fol. 253r). Unos meses después, el 6 de abril de 1579, fue nombrado capellán de la capilla de Pedro Tenorio por García de Loaysa, semanero, vacante por muerte de Morales (ib., fol. 276r).

Juan Ortega: El 3 de abril de 1579, recibió nombramiento como capellán en la capilla de Pedro Tenorio (ib., fol. 276r).

Isidro Rodríguez: Obtuvo el nombramiento de capellán en una capellanía de Alonso de Fonseca el 29 de abril de 1579 (ib., fol. 283v).

Luis Gutiérrez: Clérigo y vecino de Toledo, el 1 de junio de 1579, fue provisto por el cabildo en la capilla de San Eugenio, en la capellanía de la que había hecho dejación el clérigo Montero (ib., fol. 287v). El consistorio, reunido el 9 de junio de 1586, resolvió vacar la capellanía de Pedro Tenorio que poseía Juan de Aguirre a causa de que no residía ni servía, y la proveyó en la persona de Luis Gutiérrez (ib., tomo 18, fols. 248v-249v).

Andrés de Uxena: Vecino de Esquivias, el 3 de junio de 1579, hizo presentación al capítulo de la provisión pontificia en una capellanía de la Greda vacante por dejación de Andrés Fernández de Balboa, vecino de Valdepeñas (ib., fol. 288r).

Iglesias: El 5 de junio de 1579, fue proveído en la capellanía de Juan López de León de la que había hecho dejación Torrentes (ib., fol. 288v).

Agustín de Herrera: El 6 de junio de 1579, presentó al cabildo la provisión papal para ocupar la capellanía de Coro vaca por resignación de Gabriel de Sanabria, clérigo de Toledo, tomando posesión el 27 de agosto (ib., fols. 289r, 303r).

Juan Martínez de Corrales: Clérigo lector de la iglesia de Toledo, el 27 de agosto de 1579 , notificó al cabildo la provisión realizada por el arzobispo 
para cubrir la capellanía del Coro vacante por la muerte de Juan de Ortega (ib., fol. 303v).

Melchor Navas: La otorgación de la capellanía por parte del cabildo se produjo el 31 de agosto de 1579 (ib., fol. 304v).

Francisco de Escobar: Lector de la iglesia de Toledo, hizo presentación en el cabildo de la provisión realizada por Gaspar de Quiroga el 9 de septiembre de 1579 (ib., fol. 305v).

Alveas Méndez: Cantor, presentó al consistorio la provisión arzobispal como capellán del Coro en octubre de 1579 (ib., fol. 311v).

Bernardino de Rojas: El 2 de noviembre de 1579, notificó al cabildo la provisión realizada por Gaspar de Quiroga para una capellanía del Coro vacante por muerte de Andrés Ramírez, de la que tomó posesión el 12 de diciembre (ib., fols. 317v, 332v).

Diego de la Peña: Melchor de Ortiz le hizo traspaso de su capellanía el 8 de enero de 1580 (ib., fol. 340r).

Tadeo de Santa Cruz: Cura de Santorcaz, obtuvo presentación y nombramiento de capellán en la capilla mozárabe para cubrir la vacante producida por la muerte de Diego de Mora el 14 de junio de 1580 (ib., fol. 371v).

Licenciado Aparicio: El 17 de julio de 1580, fue presentado por Juan Manrique para ocupar la capellanía vaca por la muerte de Diego de Muros (ib., fol. 377 r).

Toribio de Nava: Clérigo, obtuvo la provisión para una capellanía de San Pedro el 27 de julio de 1580 (ib., fol. 379v).

Diego de Parra: Clérigo de la diócesis de Toledo, fue presentado por Rodrigo Dávalos, semanero, como capellán de San Pedro el 13 de septiembre de 1580 (ib., fol. 388v).

Alonso de Vega: El 13 de septiembre de 1580, presentó al cabildo la provisión arzobispal como capellán del Coro, tomando posesión el 10 de octubre (ib., fols. 389r, 396v).

Lope Sanz: Clérigo de la diócesis de Toledo, fue presentado por Rodrigo Dávalos, semanero, como capellán de San Pedro el 17 de septiembre de 1580 (ib., fol. 390v).

Francisco Vázquez: Racionero de la iglesia de Toledo, fue presentado por Tomás de Borja, semanero, como capellán de San Ildefonso el 19 de septiembre de 1580 (b., fol. 390v).

Francisco de Guzmán: Cantor, presentó al cabildo la provisión arzobispal como capellán del Coro para ocupar la vacante producida por la muerte de 
Juan de Cuéllar el 22 de septiembre de 1580, tomando posesión de la misma el 23 de diciembre (ib., fol. 392r, 416r).

Jerónimo de Loaysa: El 24 de octubre de 1580, obtuvo provisión como capellán de Sacedo para cubrir la capellanía vacante por la muerte del racionero Francisco Correas (ib., fol. 401r).

Martín de Herrera: Racionero, el 31 de octubre de 1580, fue presentado por el deán Diego de Castilla, semanero, como capellán de San Pedro (ib., fol. 402r).

Esteban Martín de los Reyes: El 5 de noviembre de 1580, hizo presentación al cabildo de la provisión realizada por Gaspar de Quiroga como capellán del Coro para ocupar la plaza vaca por la resignación hecha por Juan López, tomando la posesión el 31 de enero de 1581 (ib., fol. 404v; ib., tomo 17, fol. $8 \mathrm{v})$.

Licenciado Téllez: El 24 de noviembre de 1580, fue nombrado en una capellanía de la capilla de la Epifanía de la iglesia de San Andrés que estaba vaca por muerte del licenciado Diego de Mora (ib., tomo 16, fol. 410r).

Miguel de Llanos Barco: Tomó posesión de una capellanía del Coro el 24 de noviembre de 1580 (ib., fol. 410r).

Ruiz de Alcoholado: El 12 de diciembre de 1580, fue nombrado capellán de San Pedro en lugar de Francisco de Espinosa, quien no cumplía con la residencia (ib., fol. 413r).

Juan de Navas: El 29 de noviembre de 1580, obtuvo el nombramiento de capellán de la capilla de Pedro Ortiz (ib., fol. 410v).

Martín García de San Pedro: Fue nombrado capellán en la capilla del doctor Vergara el 29 de noviembre de 1580 (ib., fol. 410v). El 11 de mayo de 1582, presentó al cabildo la provisión arzobispal para ocupar una capellanía del Coro vaca por la promoción de Francisco de Tapia a una ración (ib., tomo 17, fols. 112r, 118v).

Cristóbal de Oseguera: El 29 de noviembre de 1580, se le otorgó nombramiento de capellán en la capilla del obispo Castillo (ib., tomo 16, fol. 410v).

Cristóbal de Gámez: El nombramiento de capellán en una capellanía de Gutiérrez Díaz fue realizado el 12 de diciembre de 1580 (ib., fol. 416r).

Alonso Torres de Carvajal: El 30 de diciembre de 1580, presentó al cabildo la provisión arzobispal para una capellanía del Coro vacante por la muerte de Alonso Gaytán de Escobedo, tomando posesión el 13 de enero de 1581 (ib., fol. 416v; ib., tomo 17, fols. 5r-v).

Juan Martínez de los Corrales: El 31 de diciembre de 1580, fue provisto en una capellanía del Nuncio (ib., tomo 16, fol. 417r). 
Juan García: Natural de Consuegra, el 2 de enero de 1581, fue dotado con una capellanía de Pedro González de Mendoza (ib., tomo 17, fol. 3r). El 22 de mayo de 1585, presentó al cabildo la provisión arzobispal para ocupar una capellanía del Coro vacante por dejación de Andrés García (ib., tomo 18, fol. $154 \mathrm{v}, 176 \mathrm{r})$.

Lucas de Andrada: El 7 de enero de 1581, obtuvo provisión para ocupar una capellanía de Pedro González de Mendoza (ib., tomo 17, fol. 4r).

Alonso de Orellana: Natural de Talavera y residente en Toledo, recibió una capellanía de Pedro González de Mendoza el 22 de febrero de 1581 (ib., fol. $13 \mathrm{v})$.

Alonso Martínez: Natural de Talavera, se le cometió una capellanía del Doctor Herrera el 7 de marzo de 1581 (ib., fol. 16v).

Michael Ferranz Muñoz: Clérigo, fue presentado, el 29 de abril de 1581, para ocupar una capellanía de la Epifanía vaca por muerte de Gonzalo de la Plaza (ib., fol. 28r).

Baltasar Suárez Salmerón: El 28 de junio de 1581, presentó al cabildo la provisión arzobispal para ocupar la capellanía del Coro vaca por la muerte de Diego de Miranda, de la que tomó posesión el 25 de agosto (ib., fol. 42r, $56 r$ ).

Juan Gómez: El 3 de julio de 1581, Gabriel de Cárdenas, semanero, hizo el nombramiento de dicho clérigo para ocupar una capellanía de San Ildefonso perteneciente al obispo de Ávila, vacante por el fallecimiento de Luis de Parra (ib., fol. 43v).

Pero Gutiérrez: El 31 de julio de 1581, presentó al cabildo la provisión arzobispal para ocupar la capellanía del Coro de la que había hecho resignación Alonso Valdivieso. Tomó posesión el 16 de octubre, aunque se realizaron ciertas contradicciones a la misma (ib., fol. 50v, 67v).

Licenciado Aranda: El 19 de agosto de 1581, fue provisto en una capellanía de Pedro González de Mendoza que estaba vaca por dejación de Juan de Aguirre (ib., fol. 54v).

Juan de Rojas: Natural de Sonseca, el 2 de septiembre de 1581, obtuvo provisión de una capellanía de Pedro González de Mendoza vaca por dejación de Gaspar de Sueldo (Ibid., fol. 57v).

Juan Beltrán: Vecino de Padilla, fue proveído en una capellanía de Pedro González de Mendoza el 13 de septiembre de 1581 (ib., fol. 62r).

Licenciado Alonso de Palenzuela: Vecino de Toledo, el 13 de septiembre de 1581, fue proveído en una capellanía de Pedro Ortiz vaca por dejación de Francisco Gutiérrez (ib., fol. 62v). 
Licenciado Cristóbal Gómez: Vecino de Toledo, obtuvo provisión en una capellanía de Pedro González de Burgos vacante por dejación del licenciado Villegas el 22 de septiembre de 1581 (ib., fol. 63r).

Alonso de Salazar: Capellán del Coro, fue proveído en una capellanía de Alonso de Fonseca, vaca por dejación de Isidro Rodríguez, el 22 de septiembre de 1581 (ib., fol. 63v).

Luis Fernández: Clérigo natural de Tarancón, el 7 de abril de 1582, obtuvo provisión en una capellanía de Pedro González de Burgos vacante por la muerte del racionero Juan Luis (ib., fol. 104r).

Bachiller Francisco Crespo: Natural de Chillaron, el 21 de agosto de 1582, obtuvo provisión de una capellanía de Juan Sacedo, que está fundada en la capilla de la Concepción de la iglesia de Toledo, vacante por la dejación que de ella hizo Jerónimo de Loaysa (ib., fol. 137r).

Licenciado Luis de Messa: El 1 de octubre de 1582, fue proveído en una capellanía de Pedro González de Mendoza (ib., fol. 148r).

Gonzalo Buxía: El 26 de noviembre de 1582, se le dio provisión de una capellanía de D. Luis Daza vacante por dejación del maestro Cristóbal de Gámez (ib., fol. 158r).

Licenciado Alonso Cebrero: Natural de Arganda, el 14 de diciembre de 1582, obtuvo provisión en una capellanía de los maestrescuelas instituida en la capilla de San Ildefonso (ib., fol. 161v).

Alonso de las Marinas: Fue proveído en una capellanía fundada por Pedro Fernández de Burgos en la capilla de los Reyes Magos el 14 de diciembre de 1582 (ib., fol. 161v).

Sebastián de Valencia: Natural de Talamanca, el 14 de diciembre de 1582, obtuvo una capellanía de Pedro Fernández de Burgos (ib., fol. 161v). El 5 de marzo de 1583, fue proveído en una capellanía de San Fernando de Illescas, fundada en la capilla de la Estrella de la iglesia de Toledo (ib., fol. 176r). El 30 de agosto de 1585, fue nominado para ocupar una capellanía de Pedro Núñez vacante por la muerte de Rodrigo Rincón (ib., tomo 18, fol. 176v).

Diego López: Natural de Toledo, el 14 de diciembre de 1582, fue nombrado capellán en una capellanía de Pedro Núñez en la capilla de San Miguel (ib., tomo 17, fol. 161v). El 19 de marzo de 1583, fue proveído en una capellanía de Pedro González de Mendoza (ib., fol. 179v).

Diego Maldonado: Natural de Toledo, obtuvo provisión en una capellanía de Pedro González de Mendoza el 14 de diciembre de 1582 (ib., fol. $161 v)$. 
Pedro de Velasco: El 8 de febrero de 1583, el licenciado Virviesca, semanero, hizo su nombramiento para una capellanía de Cristóbal Fernández vaca por la muerte del licenciado Aparicio (ib., fol. 172v).

Juan Bautista de Chaves: El secretario del cabildo fue proveído en una capellanía de San Pedro el 10 de marzo de 1583, que se encontraba vaca por la dejación realizada por Diego de Estrada. El nombramiento se efectuó ante su solicitud, a pesar de que el resto de los capellanes integrantes de dicha capilla habían pedido que esta plaza fuese reducida (ib., fols. 177v-178r).

Esteban de Luliana: Clérigo presbítero, su presentación para ocupar una capilla de la Epifanía fue realizada por Francisco de Rojas el 14 de marzo de 1583 (ib., fol. 178r).

Alonso Vega de Arnalte: El 4 de mayo de 1583, fue designado por Francisco García de Valloboso como capellán de la capilla de Pedro Tenorio, cubriendo la vacante producida por la muerte del bachiller Francisco de Herrera (ib., fol. 191v).

Francisco de Pissa: Clérigo natural de Toledo, presentó al cabildo, el 13 de junio de 1583, su nombramiento como capellán de la capilla mozárabe, cubriendo la plaza vaca por muerte de Francisco Pérez (ib., fol. 202r).

Miguel Sánchez: Bachiller y clérigo presbítero, el doctor Juan de Obregón, semanero, le nominó para una capellanía de Pedro Tenorio el 5 de octubre de 1583, vacante por la muerte de Ribera (ib., fol. 228r).

Francisco de Mesones: Natural de la Puebla de Uceda, diócesis de Toledo, fue proveído en una capellanía de Pedro Fernández de Burgos instituida en la capilla de los Reyes Magos el 5 de noviembre de 1583 (ib., fol. 235r). El 7 de abril de 1586, fue nombrado para ocupar una capellanía del Doctor Vergara, vaca por promoción de Martín de San Pedro a una ración. El nombramiento lo hizo el cabildo a petición del canónigo Juan de la Cerda (ib., tomo 18 , fol. 227v).

Luis Pérez de Villafaña: Bachiller de la ciudad de Toledo, el 7 de diciembre de 1583, obtuvo comisión para ocupar una capellanía de Gutierre Díaz (ib., tomo 17 , fol. 240r).

Licenciado Cristóbal de Olmos: Fue proveído en una capellanía de Rodrigo Ortiz el 24 de diciembre de 1583 (ib., fol. 244r).

Nicolás Solentino de Vinar: Natural de Toledo, el 7 de enero de 1584, le fue encomendada una capilla de Pedro Fernández de Burgos que está instituida en la capilla de los Reyes Magos (ib., tomo 18, fol. 5v).

Pedro López de Segura: Bachiller natural de Toledo, fue proveído en una capellanía de Rodrigo Ortiz instituida en la capilla de la Quinta Angustia el 6 de marzo de 1584 (ib., fol. 20v). 
Juan de Mariana: El 2 de mayo de 1584, el licenciado Virviesca, semanero, le nombró para ocupar una capellanía de Santa Ana vaca por muerte del maestro Damián Cedillo (ib., fol. 35v).

Baltasar de Cepeda: Natural de Toledo, fue proveido en una capellanía de Gutierre Díaz vaca por dejación de Gonzalo Buxía en 18 de mayo de 1584, con la condición de que se ordenase en un año y fuese examinado por el licenciado Gomara (ib., fol. 39v).

Juan Martínez: El 23 de agosto de 1584, presentó al cabildo la provisión arzobispal como capellán del Coro para cubrir la vacante producida por la promoción de Francisco de Guzmán a una ración (ib., fols. 68v-69r, 91r, 136v).

Diego Díaz: El 30 de agosto de 1585, fue realizado su nombramiento para ocupar una capellanía de la capilla mozárabe. Se le dió su colación tras atender la reclamación de Juan Bautista Jerónimo, cura de Santa Eulalia, que también pretendía dicha capellanía (ib., fols. 69v-70r).

Pedro Serrano: Natural de Valdemorillo, el 12 de septiembre de 1584, fue proveído en una capellanía de D. Luis Daza instituida en la capilla de los Reyes Magos (ib., fol. 74v).

Pedro Ruiz: El 17 de diciembre de 1584, hizo presentación al cabildo de la provisión arzobispal para ocupar una capellanía del Coro vaca por la muerte de Pedro Cabañas. Tomó posesión el 16 de enero de 1585 (ib., fols. 107v108r).

Juan Fernández de Quevedo: El 20 de marzo de 1585, se le encomendó una capellanía de Pedro Fernández de Burgos, vaca por la muerte del racionero Pedro Sánchez, para cantar en la capilla de la Epifanía (ib., fol. 128v).

Juan López: El 5 de junio de 1585, recibió nombramiento de capellán mayor de la capilla de San Pedro (ib., fol. 160r).

Licenciado Francisco de Rioja: El 4 de septiembre de 1585, fue presentado por Alonso de Rojas, Señor de Mora, para ocupar una capellanía de la Epifanía vaca por muerte de Esteban de Lupiana (ib., fol. 178r).

Juan Bautista Jerónimo: Clérigo natural de Toledo, fue nombrado para ocupar una capellanía de la capilla mozárabe vaca por muerte de Melchor Gutiérrez el 13 de enero de 1586 (ib., fol. 206v).

Diego Ortega: El 24 de abril de 1586, hizo presentación al cabildo de la provisión arzobispal para ocupar una capellanía del Coro vacante por dejación de Martín de San Pedro. Tomó la posesión el 2 de junio (ib., fols. 232v, 247r-v).

Pedro Hernández: El 9 de junio de 1586, presentó al cabildo la provisión realizada por Gaspar de Quiroga para ocupar una capellanía del Coro vacante por dimisión de Juan Pérez Calderón (ib., fol. 249r). 
Juan Delgado: El 8 de abril de 1587, presentó la provisión y colación realizada por Quiroga para que ocupase la capellanía del Coro de la que había hecho resignación Diego García Izquierdo. Aunque el licenciado Virviesca apeló el nombramiento, puesto que, por la relación efectuada por el doctor Navarro, Delgado sólo era clérigo de primera Corona, requiriéndose para esta capellanía la calidad de presbítero, tomó posesión de la misma el 26 de junio (ib., tomo 19 , fols. 20v, 21v, 40r).

Juan Aguado: Natural de Ciempozuelos, el 22 de junio de 1587, se le encomendó la capellanía que fundó el obispo Carrillo en la capilla de San Eugenio, atento a que su poseedor, Luis Gutiérrez, hizo dejación de ella (ib., fol. $38 \mathrm{v})$.

Alonso Sánchez: El 27 de junio de 1587, presentó al cabildo la provisión y colación por la que Quiroga le nombraba en la capellanía del Coro vaca por la resignación realizada en manos del arzobispo por Juan Núñez

Juan de San Pedro: La provisión y colación realizada por Quiroga se presentó al consistorio el 6 de julio de 1587. Ocupó la capellanía del Coro vacante por la resignación efectuada por Pedro Hernández. Tomó posesión el 26 de agosto (ib., fols. 42r-v, 53v-54r).

Sebastián de Zaballos: Vecino de Toledo, el 13 de julio de 1587, le fueron encomendadas dos capellanías del Ambitu, una de Alvar López y otra del arcediano de Toledo. Recibía por su servicio lo que fuese voluntad del cabildo (ib., fol. 43r).

Pedro Fernández: El 21 de julio de 1587, presentó al cabildo la provisión y colación otorgada por Quiroga para ocupar la capellanía del Coro vaca por muerte de Juan de Carvajal (ib., fols. 46v, 47v).

Mancio de Villafaña: El consistorio ordenó hacer colación en favor del licenciado Mancio de Villafaña de la capellanía mayor de la capilla de Corpus Christi, vaca por muerte de Juan González Camero, por nombramiento realizado por los propios capellanes de dicha capilla, siendo admitida su presentación el 7 de agosto de 1587 (ib., fol. 50r).

Rodrigo Dávalos: El capítulo catedralicio mandó escribir una carta a Felipe II, el 5 de septiembre de 1587, agradeciendo la provisión de Rodrigo Dávalos en la capellanía mayor de los Reyes Nuevos (ib., fol. 55v).

Lázaro Rincón: El licenciado Virviesca, como semanero mayor, nombró al maestro Lázaro Rincón, el 16 se septiembre de 1587, capellán de la capilla de San Pedro para cubrir la plaza del fallecido Jerónimo de Barreda (ib., fol. 58r).

Esteban Primo: Racionero de Salamanca, el 24 de septiembre de 1587, fue proveído en la capellanía de San Pedro que tenía encomendada Martín de Herrera, que fue destituido por el cabildo porque no la servía (ib., fol. 60v). 
Cristóbal Rojo: El 4 de enero de 1588, presentó al consistorio la provisión y colación realizada por Quiroga para cubrir la capellanía del Coro vaca por haber entrado en religión y tener hecha profesión Juan Martínez Centeno. Tomó posesión el 17 de febrero (ib., fols. 77r, 88v).

Antonio de Villalobos: Clérigo de Toledo, fue nombrado por Juan de Alarcón, semanero mayor, para ocupar la capellanía de Pedro Tenorio vaca por muerte de Martín Pérez (ib., fols. 79v-80r).

Juanes de Arrastra: Natural de Iruñuela, en el obispado de Pamplona, el cabildo le encomendó, el 14 de enero de 1588, una de las capellanías de don Juan Salcedo que se cantaba en la capilla de la Concepción, que vacó por dejación de Francisco Crespo, racionero (ib., fol. 80r).

Francisco de Guzmán: Racionero, fue nombrado por el cabildo para ocupar una capellanía vaca de Alonso de Rojas, el 8 de febrero de 1588, quedando anulado el nombramiento realizado por el canónigo Francisco de Monsalve, semanero mayor, en el racionero Samaniego (ib., fol. 86r).

Lorenzo Carranza: Licenciado y natural de Toledo, el consistorio le encomendó, el 17 de marzo de 1588, una de las capellanías de don Juan Salcedo fundadas en la capilla de la Concepción (ib., fol. 96v).

Diego de Orgaz: Sacerdote, el cabildo le nombró capellán de la capilla de Alonso de Fonseca el 29 de abril de 1588, en la plaza vaca por dejación de Juan Manrique (ib., fol. 106r).

Gabriel Díaz: Clérigo y licenciado, el 8 de agosto de 1588, presentó la provisión y colación hecha por Quiroga, por la que le proveía en una capellanía del Coro vaca por muerte de Gutierre Capoche. Tomó posesión el 23 de septiembre (ib., fols. 127r, 136r-v).

Pedro Martínez: Clérigo natural de Illescas, fue nombrado por el licenciado Virviesca, semanero mayor, en una capellanía de doña Teresa de Haro el 15 de septiembre de 1588 (ib., fol. 135r).

Alejo Martínez: Clérigo, el 26 de septiembre de 1588, notificó al consistorio la colación y provisión realizada por Quiroga como capellán del Coro en la capellanía vaca por resignación que Vasco de Quemada hizo en manos del prelado. Tomó posesión el 15 de diciembre (ib., fols. 148v, 153r-v).

Pedro Gallego: Quiroga otorgó provisión y colación para que ocupase la plaza vacante en la capilla del Coro por muerte de Pedro de Palmas. El 2 de diciembre de 1588, realizó la presentación de la misma al cabildo, tomando posesión el 23 de febrero de 1589 (ib., fols. 151r-v, 169v).

Luis de Huerta: El 23 de diciembre de 1588, presentó al cabildo la bula y letras apostólicas por las que le papa le proveía como capellán del Coro en la vacante existente por resignación de Luis de Huerta, cura de la parroquia de 
la Guardia en manos del pontífice y en favor de Luis de Huerta el mozo. Tomó posesión el 14 de marzo de 1589 (ib., fols. 154v, 157r, 174v-175r).

Francisco Merchante: Por haberse ausentado de la ciudad Juan Fernández de Quevedo, vacó la capellanía de don Luis Daza que poseía, encomendándola el consistorio, el 2 de enero de 1589, a Francisco Merchante (ib., fol. 156v).

Benito Sánchez: Bachiller y vecino de Estremera, el 27 de enero de 1587, presentó al cabildo la provisión y colación hecha por Quiroga, por la que le nombraba capellán del Coro en la vacante producida por la resignación realizada por Bartolomé Sánchez. Tomó posesión el 14 de marzo (ib., fols. 161v-162r, 163v-164r, 174v-175r).

Cristóbal Rodríguez: Bachiller y natural de Toledo, el 7 de marzo de 1589, el consistorio le nombró capellán de dos capellanías, una del arcediano de Toledo Siruela y otra de Pedro Fernández de Villalobero, que estaban fundadas en la capilla de San Gil (ib., fol. 173r).

Tomás Palmero: El 21 de marzo de 1589, presentó al cabildo el nombramiento realizado por Francisco de Rojas, patrón de la capilla de la Epifanía, por el que se le designaba capellán para cubrir la vacante producida por la muerte de Alonso Chacón (ib. fol. 178r).

Pedro de Herrera: Natural del arzobispado de Toledo, el cabildo le encomendó, el 23 de marzo de 1589, una capellanía de Lucas de las Peñas, vacante por dejación de Tomás Palmero (ib., fol. 182v).

Simón de Carranza: Licenciado y racionero, fue proveído por Juan de la Cerda, semanero mayor, en dos capellanías vacas, una de Diego Rodríguez de Oviedo y otra de Sancho Fernández (ib., fol. 187v).

Juan Bautista de Chaves Arcayos: El 24 de abril de 1589, presentó al consistorio la provisión y colación hecha por Quiroga para cubrir la plaza de capellán del Coro vacante por la muerte de Juan de Valladolid. Tomó posesión el 30 de junio (ib., fols. 190r-v, 206r-v).

Jerónimo Hernández: Presentó la provisión y colación realizada por el arzobispo al cabildo el 5 de mayo de 1589. Por ésta, quedaba proveído en la capellanía del Coro vacante por la resignación efectuada por Pedro Ruiz. Tomó posesión el 3 de julio (ib., fols. 192v, 195r, 206v-207r).

Pedro Martínez: Clérigo presbítero, fue presentado, el 12 de mayo de 1589, por el licenciado Virviesca, semanero mayor, para una capellanía de San Pedro vaca por muerte de Jerónimo Páez (ib., fol. 193v).

Alonso Niño: Canónigo, el 4 de septiembre de 1589, Francisco de Rojas, patrón de la capilla de la Epifanía, le nombró capellán mayor de la misma, puesto que se encontraba vaco por la muerte de Pedro de Ayala (ib., fol. 222r). 
Pedro Hernández: Clérigo presbítero y capellán del Coro, fue nombrado por Álvaro de Monsalve en una capellanía de Pedro Tenorio, de la que se había exonerado Alonso Díaz, el 10 de abril de 1590 (ib., tomo 20, fols. 26v-27r, $31 r)$.

Cristóbal Rubio: El 2 de mayo de 1590, presentó al cabildo la provisión y colación hecha por Quiroga para que ocupase la capellanía del Coro vaca por muerte de Baltasar Suárez. Tomó posesión el 12 de agosto (ib., fols. 40v$41 \mathrm{v}, 60 \mathrm{v}, 69 \mathrm{r})$. El 4 de febrero de 1594, el consistorio le encomendó la capellanía de Pedro Fernández de Burgos que estaba vacante por dejación de Jerónimo Ximénez (ib., tomo 21, fol. 113v). Así mismo, el 10 de marzo del mismo año, el capítulo le proveyó en una de las capellanías de Juan Duque de Strada, de la que hizo dejación Juan del Corral con licencia del Consejo arzobispal (ib., fol. 120v).

Alonso de Yegros: Clérigo y licenciado, el 24 de mayo de 1590, presentó al consistorio su nombramiento para la capilla de la Epifanía en la vacante producida por la muerte de Diego de Salazar (ib., tomo 20, fols. 51v-52r).

Diego Fernández de Párraga: Vecino de Toledo, fue proveído por el cabildo, el 8 de agosto de 1590, en una capellanía de la capilla de San Miguel, dotada por Pedro Núñez, que había dejado vaca su anterior poseedor, el clérigo Sebastián de Valencia (ib., fol. 68v).

Francisco de Vega Arnaldo: A petición del tesorero Francisco García de Valloboso, fue proveído, el 18 de agosto de 1590, en una capellanía de la capilla de la Concepción dotada por don Juan Salcedo, de la que había hecho dejación Cristóbal de Vargas. Era natural de Dosbarrios (ib., fol. 70r).

Diego de Buenalma: El licenciado Gomara, semanero mayor, hizo el nombramiento en la capellanía vaca en la capilla de San Miguel por muerte del licenciado Diego Hernández de Párraga el 13 de septiembre de 1590. Era clérigo y criado de Pedro de Carvajal (ib., fol. 77r).

Juan Gómez: Bachiller y vecino de Ajofrín, fue nominado por el cabildo, el 13 de septiembre de 1590, para ocupar la capellanía dotada por Pedro Fernández de Burgos en la capilla de la Epifanía, que vacó por dejación de Luis Hernández, vecino de Tarancón (ib., fol. 77v).

Juan de Fuentes: Natural de Pezuela, el 15 de septiembre de 1590, presentó al consistorio la provisión y colación realizada por Quiroga, por la que le proveía en el capellanía del Coro vaca por muerte de Pedro Ortiz. Tomó posesión el 17 de octubre (ib., fols. 79r, 84r).

Gómez de Mendoza: Racionero, fue nominado por Andrés Fernández, semanero mayor, en una capellanía de Pedro González de Mendoza, vaca por muerte de Pedro de Ortiz, el 29 de diciembre de 1590 (ib., fol. 98r-v). 
Licenciado Ayora: Clérigo, fue designado por Andrés Fernández, semanero mayor, el 29 de diciembre de 1590, para ocupar una capellanía en la capilla de San Ildefonso vaca por muerte de Juan Rodríguez, vecino de Toledo (ib., fols. 98r-v, 100r).

Fernando de Carvajal: Clérigo presbítero, era natural de Toledo. Fue nombrado por Pedro de Carvajal en una capellanía de San Pedro vaca por la muerte del clérigo Toribio de Nava el 1 de marzo de 1591 (ib., fol. 117v).

Gonzalo Pérez: El 7 de marzo de 1591, el cabildo le encomendó la capellanía de Rodrigo Tenorio que estaba fundada en el sepulcro, vacante por la dejación hecha por el licenciado Fernando de Carvajal (ib., fol. 118v).

Pablo Rubio: El 6 de abril de 1591, dicho clérigo presentó al consistorio la provisión y colación realizada por Quiroga, por la que le proveía en la capellanía del Coro vaca por la ausencia de Luis Martínez. Tomó posesión el 29 de mayo (ib., fols. 128v, 143v).

Miguel Ortega: Ocupó la vacante producida de una capellanía del Coro por la resignación que hizo Francisco de Ortega en manos de Quiroga. El 27 de abril de 1591, presentó al cabildo la provisión y colación por la que era proveído en la misma, tomando posesión el 30 de mayo (ib., fols. 128v, 143v).

Francisco Evangelista: Gabriel Suárez, el 25 de mayo de 1591, le nombró para ocupar la capellanía de San Pedro vaca por muerte de Tomás Palmero (ib., fol. 140v).

Alonso Merchante: El 5 de junio de 1591, presentó al cabildo la provisión y colación hecha por Quiroga, por la que le proveía en una capellanía del Coro, en la vacante producida por el fallecimiento de Gonzalo de Villanueva, tomando la posesión el día 27 de dicho mes (ib., fols. 146r, 152v).

Alonso Guio: Natural de Toledo, el 5 de junio de 1591 notificó al consistorio la bula y letras apostólicas por las que era proveído en la capellanía del Coro vaca por la resignación hecha en manos del pontífice por Luis de Huerta. Tomó posesión el 7 de agosto (ib., fols. 146v-147r, 163r).

Andrés Pacheco: Francisco de Rojas, patrón de la capilla de la Epifanía, realizó el nombramiento para ocupar la vacante producida en la misma por la muerte de Tomás Palmero, que el licenciado Pacheco presentó al cabildo el 27 de junio de 1591 (ib., fol. 152v).

Juan de Aliende: Racionero, fue nominado por Andrés Fernández, semanero mayor, el 24 de julio de 1591, para ocupar la capellanía de Juan López de León, vaca por el fallecimiento del racionero Antonio López Salcedo (ib., fol. 160r).

Antonio de Tavares: Pedro de Carvajal, semanero mayor, le proveyó en la capellanía en el altar de Santa Elena, vaca por la muerte de Bartolomé Quevedo, el 30 de agosto de 1591 (ib., fol. 169r). 
Pedro Martínez de Torres: El 19 de septiembre de 1591, hizo presentación al capítulo de la provisión y colación realizada por Quiroga para que ocupase la capellanía del Coro vaca por la resignación hecha por Sebastián de Mudarra. Tomó posesión el 19 de noviembre (ib., fols. 174r, 188r-v).

Andrés Guio de Llanos: Racionero, fue nombrado por Alonso Niño, el 2 de octubre de 1591, en la capellanía de Juan López de León, que vacó por la muerte del racionero Aliende (ib., fol. 177v). Igualmente, Bernardino de Sotomayor, semanero mayor, el 19 de abril de 1592, le nombró en una capellanía de Pedro González de Mendoza vaca por el fallecimiento del racionero Amocibar (ib., fol. 230r).

Juan Corral: Ginés de Soto le designó, el 2 de octubre de 1591, para ocupar la capellanía de Juan Duque de Strada en el sepulcro, que estaba vacante por fallecimiento de Dámaso de Ribera (ib., fol. 178r).

Ginés del Río: El cabildo le encomendó la capellanía del tesoro que dejó Juan de Campoverde el 2 de octubre de 1591 (ib.).

Francisco Ximénez: El 7 de enero de 1592, presentó al consistorio la colación hecha por el arzobispo, por la que le proveía en una capellanía del Coro vaca por la muerte de Juan Criado. Tomó posesión el 14 de marzo (ib., fols. 196v, $222 \mathrm{v})$.

Francisco de Zárate: Natural de Toledo, el capítulo le encomendó, el 4 de febrero de 1592, una capellanía de don Juan Salcedo en la capilla de la Concepción, que vacó por dejación del licenciado Juan de Olías (ib., fol. 208r).

Antonio Gracián: Clérigo presbítero, el 20 de febrero de 1592, Ginés de Soto le nombró en una capellanía de San Pedro vaca por el fallecimiento del maestro Rincón (ib., fol. 214r).

Juan Sánchez: Bachiller y natural del Campo, el 24 de febrero de 1592, el cabildo le cometió dos capellanías, una de los maestrescuelas y otra del abad de San Vicente, vacantes por dejación del licenciado Pedro de Morales (ib., fol. 215v).

Cristóbal Hernández: Licenciado y vecino de Toledo, los capellanes de la capilla mozárabe le nombraron por tal en la capellanía que estaba vacante por muerte de Bernabé de Tamayo el 13 de marzo de 1592 (ib., fol. 220r).

Luis de Velas: El 10 de marzo de 1592, el consistorio le encomendó dos capellanías de Gutierre Díaz en la capilla de la Trinidad, vacas por dejación de Eugenio Camacho (ib., fol. 221v).

Domingo de Alvear: Natural de Ampuero, en la diócesis de Burgos, el 16 de abril de 1592, el capítulo le cometió una capellanía de doña Mencía de Haro y otra de don Gutierre (ib., fol. 229r). 
Miguel Campillo: Natural de Toledo, el 21 de abril de 1592, el cabildo le otorgó dos capellanías, una del capiscol Fernando de Illescas y otra del doctor Herrera de que hizo dejación Juan Ruíz, clérigo, con licencia del Consejo arzobispal (ib., fol. 131v).

Miguel García: Clérigo de Corona y Grados de la diócesis de Cuenca, el consistorio le cometió, el 13 de julio de 1592, una capellanía de la capilla de San Bricio dotada por doña Catalina Ramírez (ib., fol. 251r-v).

Antonio de Guzmán: Clérigo de Grado, vecino de la Guardia, el capítulo le encomendó, el 15 de junio de 1592, la capellanía del Ambitu que instituyó Fernando de Illescas, después de admitir la dejación que hizo el licenciado Alderete de Pantoja, vecino de Valdemoro (ib., fol. 245v).

Alonso Niño de Zúñiga: El 22 de junio de 1592, hizo presentación al cabildo de la bula apostólica por la que era proveído en la capellanía mayor de la iglesia de Toledo, por resignación simple que hizo Juan de Vargas en manos del pontífice (ib., fols. 247r-248r)

Miguel García: Clérigo de Corona y Grados de la diócesis de Cuenca, el consistorio le cometió, el 13 de julio de 1592, una capellanía de la capilla de San Bricio dotada por doña Catalina Ramírez (ib., fol. 251r-v).

Pedro Sánchez: Racionero, el 24 de julio de 1592, el capítulo le nombró primer capellán de la capilla fundada por Francisco García Valloboso (ib., fol. 253v).

Miguel de Burgos: Clérigo de Evangelio, Gabriel Suárez, semanero mayor, le presentó el 22 de octubre de 1592, para ocupar la capellanía de Pedro Tenorio vaca por muerte de Simón de Cuevas, siendo admitido (ib., fol. 273r-v).

Luis Moreno: El 31 de octubre de 1592, hizo presentación al cabildo de la provisión y colación hecha por Quiroga para ocupar la capellanía del Coro vacante por el fallecimiento de Simón de Cuevas. Tomó posesión el 7 de diciembre (ib., fols. 275r, 281v).

Juan Gutiérrez: Natural de Alcalá de Henares, el consistorio le encomendó, el 16 de diciembre de 1592, dos capellanías del Ambitu, una del abad de San Vicente y otra de los maestrescuelas, por dejación de Juan Sánchez, vecino de la villa del Campo (ib., fol. 283v).

Agustín Fernández: De la diócesis de Segovia, el 30 de mayo de 1593, el cabildo le proveyó en una de las capellanías que fundó el doctor Vergara en el Hospital del Nuncio, vacante por el fallecimiento del bachiller Juan de Campoverde. Igualmente, al día siguiente, le encomendaron dos capellanías que el maestre de Santiago don Álvaro de Luna fundó en la capilla de Santiago, de las que había hecho dejación el licenciado Juan de Guemes. Obtuvo licencia del Consejo arzobispal, puesto que, por sus otras provisiones no po- 
día servir en todas. No obstante, el 28 de agosto de 1594, Tomás de Borja le designó para ocupar la capellanía del obispo de Ávila, vaca por dejación del licenciado Ayora (ib., tomo 21, fols. 25v, 26r, 155r).

Juan de Fuentes: Clérigo presbítero, presentó al cabildo, el 25 de junio de 1593 , la provisión y colación hecha por Quiroga, por la que era proveído en la capellanía del Coro vaca por muerte de Diego Fernández de Ortegón. Tomó posesión el día 30 del mismo mes (ib., fols. 50r, 51r-v).

Luis de Ávila: El 26 de junio de 1593, Francisco de Rojas, patrón de la capilla de la Epifanía, nombró al maestro Luis de Ávila capellán de la misma para cubrir la vacante producida por el fallecimiento de Gabriel Pérez (ib., fol. $50 \mathrm{v})$.

José de Valdivieso: El 30 de junio de 1593, notificó al cabildo la nominación del capellán mayor y de los capellanes de la capilla mozárabe para ocupar una capellanía de la misma vaca por muerte de Diego Hernández de Ortegón. Tomó posesión el 9 de julio (ib., fols. 50v-51r, 52v-53r).

Miguel García: Natural de Tarancón, en la diócesis de Cuenca, y residente en la ciudad de Toledo, fue nombrado por el consistorio para ocupar una capellanía de las de Pedro Fernández de Burgos en la capilla de la Epifanía el 9 de septiembre de 1593, cuando admitieron la dejación realizada por Juan Gómez, clérigo presbítero de la villa de Ajofrín, que no la podía servir por estar residiendo en dicha población, donde tenía otra capellanía (ib., fol. $68 r$ ).

Gregorio López: Clérigo de Grados y sacristán del Hospital de Santa Cruz, el 13 de septiembre de 1593, fue nominado por el capítulo en dos capellanías, una de Cristóbal Velázquez en la capilla de Santa Lucía, y otra de Hernán Pérez de Ayala en la capilla de Nuestra Señora de la Estrella, de las que hizo dejación el licenciado Antonio Calderón, cura propio de San Bartolomé de Sonsoles en Toledo (ib., fol. 69v).

Alonso López: El 5 de noviembre de 1593, hizo presentación al consistorio de la provisión y colación realizada por el arzobispo, por la que era proveído en la capellanía de Coro vaca por muerte de Gabriel Pérez (ib., fol. 90r).

Cristóbal Hernández: Rodrigo Dávalos, semanero mayor, le nombró, el 26 de noviembre de 1593, en la capellanía de San Pedro vaca por el fallecimiento de Pedro de Acebedo (ib., fols. 94v-95r).

Alonso Campillo: El 26 de noviembre de 1593, Rodrigo Dávalos, semanero mayor, le nominó para ocupar una capellanía de doña Teresa de Haro, que estaba vacante por la muerte de Pedro de Acebedo (ib.).

Jerónimo de la Fuente: Licenciado y natural de Toledo, Bernardino de Sotomayor, semanero mayor, le designó capellán en la capilla de Pedro Tenorio, 
en la vacante producida por el fallecimiento de Alonso Maldonado (ib., fol. 98r).

Juan de Mora Halcón: El 20 de diciembre de 1593, hizo presentación al consistorio de la provisión de una capellanía del Coro realizada por el arzobispo, que se encontraba vacante por la resignación hecha en manos del prelado por Juan de Fuentes (ib., fol. 113v).

Marcos de Lara: El capítulo le encomendó, el 4 de febrero de 1594, dos capellanías, una del capiscol Fernando de Illescas, y otra del doctor Herrera, que vacaron por dejación de Miguel Campillo (ib., fol. 113v).

Juan Fernández Suárez: El 15 de febrero de 1594, presentó al cabildo la colación realizada por Quiroga, por la que era proveído en la capellanía del Coro vaca por la muerte de Juan Gómez. Tomó posesión el 28 de junio (ib., fols. 115r, 142r, 145r).

Alonso de las Mariñas: Racionero, el 17 de febrero de 1594, el consistorio le encomendó la capellanía del cardenal Pedro González de Mendoza que vacó por dejación del racionero Gómez de Mendoza (ib., fol. 115v).

Licenciado Gomara: El cabildo le nombró, el 7 de mayo de 1594, capellán de la capilla que dotó Gabriel de Cárdenas en el altar de Nuestra Señora de Gracia (ib., fol. 135r).

Blas González: Clérigo presbítero, el 13 de mayo de 1594, Francisco de Espinosa, semanero mayor, le nombró capellán de San Pedro en la capellanía vaca por la muerte de Francisco de Torres Carvajal (ib., fol. 136v).

Benito Arroyo Ballesteros: El 7 de junio de 1594, el licenciado Gomara, semanero mayor, le nominó para la capellanía del arcediano de Siruela, vaca por el fallecimiento de Cristóbal Rodríguez (ib., fol. 140r).

Pedro González Pantoja: Por la muerte de Cristóbal Rodríguez, el licenciado Gomara, semanero mayor, designó a Pedro González Pantoja en la capellanía de Pedro Fernández de Burgos que había quedado vacante el 7 de junio de 1594 (ib.).

Lucas Ximénez: El cabildo le encomendó, el 23 de junio de 1594, una capellanía del arcediano de Guadalajara, fundada en la capilla de Santa Lucía, vacante por dejación del licenciado Villafañe (ib., fol. 143r).

Diego Ballesteros: El 15 de septiembre de 1594, el licenciado Gomara, semanero mayor, le nombraba capellán de San Pedro en la capilla vaca por el fallecimiento de Andrés de Arévalo (ib., fol. 159r).

Alonso Muñoz: El 28 de septiembre de 1594, notificó al cabildo la provisión y colación realizada por Quiroga, por la que le proveía en la capellanía del Coro vaca por muerte de Gaspar Machuca (ib., fol. 162r). 


\section{CLERIZONES:}

Francisco de Luz: Vecino de San Martín de la Vega, obtuvo nombramiento el 2 de noviembre de 1577 (ib., tomo 16, fol. 142r).

Antonio Serrano: Vecino de Toledo, fue nombrado el 7 de marzo de 1578 (ib., fol. 178v).

Domingo de Morales: Recibió el nombramiento el 24 de octubre de 1578 (ib., fol. 245).

Blas Ortega: Vecino de Villaseca, obtuvo el nombramiento el 14 de noviembre de 1578 (ib., fol. 251v).

Juan Gómez: Vecino de Toledo, fue admitido el 29 de noviembre de 1578, recibiendo nombramiento el 10 de abril de 1579 (ib., fols. 252r, 280r).

Alonso de Salazar: Fue recibido el 5 de diciembre de 1578 (ib., fol. 252v).

Francisco Merchante y Alonso Merchante: Fue recibido el 5 de diciembre de 1578 (ib., fol. 252v).

Francisco Muñoz: Vecino de Castil de Vayuela, fue nombrado el 2 de marzo de 1579 (ib., fol. 269v).

Blas Hernández: Vecino de Añover, fue nombrado el 29 de abril de 1579 (ib., fol. 283v).

Juan López Romero: Vecino de Torrejoncillo, diócesis de Cuenca, obtuvo nombramiento el 5 de junio de 1579 (ib., fol. 288v).

Agustín de Ocaña: Vecino de Seseña, fue admitido el 21 de julio de 1579, siendo recibido el 28 de septiembre (ib., fols. 297v, 309r).

Francisco Sánchez: Natural de Carrión, fue recibido el 28 de septiembre de 1579 (ib., fol. 309r).

Cristóbal de Valdepareja: Paje del deán Diego de Castilla, fue recibido el 17 de noviembre de 1579 (ib., fol. 322r).

Felipe de la Oliva: Fue recibido el 16 de enero de 1580 (ib., fol.344r; ib., tomo 17, fol. 40v, 149r).

Hernán Joan: Vecino de Miguelturra, fue recibido el 11 de julio de 1580 (ib., tomo 16, fol. 371r).

Antón de Bolaños: Vecino de Ciudad Real, fue recibido el 21 de julio de 1580 (ib., fol. 378r).

Juan Castellano: Vecino de Ajofrín, fue recibido el 27 de julio de 1580 (ib., fol. 379r).

Alonso Gómez: Natural de Dos Barrios, obtuvo su recibimiento el 1 de octubre de 1580 (ib., fol. 394v). 
Alonso Pérez: Vecino de Getafe, fue nombrado el 17 de noviembre de 1580 (ib., fol. 409r; ib., tomo 17, fol. 3r).

Blas Martín: Natural de Hazaña, obtuvo nombramiento el 14 de diciembre de 1580 (ib., tomo 16, fol. 413v; ib., tomo 17 , fol. 19r).

Felipe Hernández: Natural de Ajofrín, fue recibido el 13 de enero de 1581 (ib., fol. $5 r)$.

Miguel López Romero: Natural de Torrejoncillo, diócesis de Cuenca, fue recibido el 1 de febrero de 1581 (ib., fols. 8v, 21r).

Eugenio Ruiz: Expósito, fue recibido el 4 de febrero de 1581 (ib., fol. 9v).

Antonio Ciruelo: Natural de Valdemoro, fue admitido el 16 de marzo de 1581 (ib., fol. 19r).

Diego de Bolaños: Natural de Ciudad Real, fue admitido el 20 de marzo de 1581 (ib., fol. 19v).

Lorenzo González: Natural de Toledo, fue recibido el 1 de junio de 1581 (ib., fol. $32 \mathrm{v})$.

Juan de Vega Arnalte: Fue recibido el 8 de junio de 1581 (ib., fol. 35v).

Melchor de Cuadros: Fue seise de la iglesia de Toledo. Fue recibido el 17 de junio de 1581 (ib., fol. 38v).

Andrés de Magán: Fue recibido el 17 de junio de 1581 (ib., fol. 39r).

Luis de la Cruz: Recibido el 17 de junio de 1581 (ib., fol. 39r).

Juan Bautista del Rincón: Recibido el 17 de junio de 1581 (ib., fol. 39r).

Alonso Martín: Fue recibido el 17 de junio de 1581 (ib., fol. 39r).

Juan Bautista Martínez: Fue recibido el 23 de junio de 1581, formalizándose su admisión el 20 de diciembre del año siguiente (ib., fol. 40v, 163r).

Alonso Galán: Natural de Hernancanónigo, fue recibido el 5 de julio de 1581 (ib., fol. $43 \mathrm{v}$ ).

Damián Martín: Fue recibido el 6 de julio de 1581 (ib., fol. 44v).

Alonso de Quincoces: Recibido el 10 de julio de 1581 (ib., fol. 45v).

Baltasar García: Fue recibido el 14 de julio de 1581 (ib., fol. 46v).

Luis de Aguilera: Natural de las Ventas, fue recibido el 24 de julio de 1581 (ib., fol. 48r).

Juan de Ocaña: Fue recibido el 27 de julio de 1581 (ib., fol. 49v).

Esteban Benitos: Recibido el 27 de julio de 1581 (ib., fol. 49v).

Andrés Benitos: Fue recibido el 27 de julio de 1581 (ib., fol. 49v).

Andrés López: Recibido el 29 de julio de 1581 (ib., fol. 50r). 
Agustín de Xuera: Fue recibido el 29 de julio de 1581 (ib., fol. 50r).

Jerónimo de Mora: Recibido el 29 de julio de 1581 (ib., fol. 50r).

Miguel Gómez: Fue recibido el 8 de agosto de 1581 (ib., fol. 51r).

Gregorio de Ayala: Fue recibido el 11 de agosto de 1581 (ib., fol. 52v).

Juan Gómez: Natural de Toledo, fue recibido el 16 de agosto de 1581 (ib., fol. $53 \mathrm{v})$.

Diego de Portillo: Recibido el 19 de agosto de 1581 (ib., fol. 54v).

Miguel Ortega: Fue recibido el 30 de agosto de 1581, formalizándose su admisión el 17 de noviembre (ib., fols. 56v, 76r).

Alonso Pérez: Admitido el 15 de septiembre de 1581 (ib., fol. 62v).

Bartolomé Sanz: Fue admitido el 22 de septiembre de 1581, siendo finalmente recibido el 18 de abril de 1582 (ib., fol.63v, 106r).

Pedro García Luengo: Recibido el 2 de octubre de 1581, formalizó su admisión el 17 de septiembre de 1583 (ib., fol. 64v, 223v).

n: Fue recibido el 2 de octubre de 1581 (ib., fol. 64v).

Alonso de Junquera: Recibido el 2 de octubre de 1581 (ib., fols. 64v, 85r).

Pero Ruiz: Recibido el 2 de octubre de 1581, formalizó su admisión el 13 de enero de 1582 (ib., fols. 64v, 87v).

Francisco de Guzmán: Fue recibido el 9 de octubre de 1581 (ib., fol. 65v).

Domingo Moreno: Recibido el 3 de noviembre de 1581 (ib., fols. 71v, 80v).

Marcos de Uriarte: Recibido el 3 de noviembre de 1581, formalizó su admisión el 8 de agosto de 1582 (ib., fols. 71v, 135r).

Luis Frontal: Fue recibido el 6 de septiembre de 1581 (ib., fol. 72r).

Francisco Mudarra: Fue recibido el 6 de septiembre de 1581 (ib., fols. 72r, 138r).

Simón Cuadrado: Fue recibido el 23 de diciembre de 1581 (ib., fols. 83v, 85r, $145 \mathrm{v})$.

Tomás Rodríguez: Recibido el 23 de diciembre de 1581 (ib., fols. 83v, 85r, $99 \mathrm{v})$.

Juan Molero: Fue admitido el 3 de enero de 1582 (ib., fol. 85r).

Juan de Ocaña: Admitido el 31 de enero de 1582 (ib., fol. 90v).

Simón Hernández y José Hernández: Hermanos, fueron recibidos el 24 de marzo de 1582. El 8 de marzo de 1583 Simón fue admitido como seise (ib., fols. 100v, 176v).

Juan Calderón: Admitido el 29 de marzo de 1582 (ib., fol. 102r). 
Baltasar García: Fue admitido el 30 de mayo de 1582 (ib., fol. 117v).

Juan Gómez: Fue admitido el 4 de julio de 1582 (ib., fol. 126r).

Alonso Serrano: Admitido el 13 de septiembre de 1582 (ib., fol. 143v).

Juan Benito: Fue admitido el 17 de septiembre de 1582 (ib., fol. 145r).

Pedro Alfonso de Huerta: Admitido el 22 de noviembre de 1582 (ib., fol. 157r).

Francisco Martín: Maestro natural de Ajofrín, fue admitido el 3 de enero de 1583 (ib., fol. 165v).

Juan Gómez: Natural de Morata, fue admitido el 26 de enero de 1583 (ib., fols. 170r, 224v).

Francisco Pedrero: Natural de San Martín de Valdeiglesias, fue admitido el 3 de marzo de 1583, formalizando la dicha admisión el 26 de septiembre (ib., fols. $175 \mathrm{v}, 225 \mathrm{v}$ ).

Alonso Ruiz de la Franca: Natural de Almagro, fue recibido el 22 de abril de 1583 (ib., fols. 189r, 241v).

Juan Ángel: Fue admitido el 7 de mayo de 1583 (ib., fol. 192v).

Juan Sánchez: Natural de Pulgar, fue admitido el 9 de mayo de 1583 (ib., fols. 193r, 235r).

Gabriel Serrano: Natural de Escalona, fue admitido el 15 de julio de 1583 (ib., fols. 211r, 217r).

Alonso Lozano: Admitido el 23 de septiembre de 1583 (ib., fol. 224v).

Jerónimo López: Hijo de Pedro López y Susana López, vecinos de Toledo, fue recibido el 8 de octubre de 1583 (ib., fol. 229r).

Pero López de Yela: Admitido el 26 de octubre de 1583 (ib., fol. 234r).

Gino de Gaseciena: Fue admitido el 28 de noviembre de 1583 (ib., fol. 238v).

Miguel Gómez: Admitido el 30 de enero de 1584 (ib., tomo 18, fol. 13r).

Francisco Gonzalo: Natural de Fuencarral, fue admitido el 27 de septiembre de 1584 (ib., fols. 77v, 93v).

Gaspar Ximénez: Fue recibido el 29 de octubre de 1584 (ib., fols. 84v, 87r).

Miguel Crespo: Fue admitido el 2 de diciembre de 1585 (ib., fol. 198v).

Pedro Díaz: Natural de la villa de Mora, fue admitido el 22 de marzo de 1586 (ib., fol. 224v).

Pedro de Moragón: Natural de Villa Robledo, fue admitido el 24 de abril de 1586 (ib., fol. 232v). 
Gregorio Baltanas: Natural de Parla, fue recibido el 16 de junio de 1586 (ib., fol. 251v).

Francisco Romero: Admitido el 23 de junio de 1586 (ib., fol. 252v).

Juan Serrano: Fue admitido el 25 de junio de 1586 (ib., fol. 252v).

Andrés de Soria: Fue admitido el 14 de febrero de 1587 (ib., Vol.19, fol. 10v).

Francisco Vázquez: Natural de Dosbarrios, fue recibido el 26 de febrero de 1587 (ib., fol. 12v).

Diego Martínez: Admitido, igualmente, el 26 de febrero de 1587, era natural de Lillo (ib.).

Pedro Díaz: Natural de Cerralvo, fue admitido el 10 de febrero de 1588 (ib., fol. 86v).

Sebastián López y Zacarías García: Fueron admitidos el 15 de febrero de 1588 (ib., fol. 88r).

Pablo Gutiérrez: Fue admitido el 17 de febrero de 1588 (ib., fol. 89r).

Gaspar Maldonado y Eugenio de Tarazona: Obtuvieron su admisión el 24 de febrero de 1588 (ib., fol. 91r).

Pedro de Juera: Admitido el 17 de marzo de 1588 (ib., fol. 89r).

Diego Garroz: Natural de Yebenes, fue admitido el 31 de marzo de 1588 (ib., fol. 98v).

Alonso de Ocaña: Natural de Valdemoro, fue admitido el 31 de marzo de 1588 (ib.).

Miguel López: El 17 de mayo de 1588, se admitió a Miguel López, natural de Toledo (ib., fol. 112r).

Juan de Castaneda: Fue admitido el 27 de junio de 1588 (ib., fol. 117v).

Juan de Mora y Miguel Martín: Fueron admitidos el 12 de septiembre de 1588 (ib., fol. 134v).

Francisco Muñoz: Natural de Toledo, fue admitido el 15 de septiembre de 1588 (ib., fol. 135v).

Juan Calvo: Admitido el 19 de septiembre de 1588 (ib.).

Luis López de Vega y Antonio Sánchez Halcón: Ambos naturales de Dosbarrios, fueron admitidos el 26 de septiembre de 1588 (ib., fol. 136v).

Juan de Arriba: Fue hecha la admisión el 19 de octubre de 1588 (ib., fol. $140 \mathrm{v})$.

Antonio de la Parra y Alonso Gómez Domínguez: Admitidos el 22 de octubre de 1588 (ib., fol. 141r). 
Alonso González y Pedro Fresno: Fueron admitidos el 12 de diciembre de 1588 (ib., fol. 152v).

Diego Nieto: Natural de Ventosa, fue admitido el 22 de abril de 1589 (ib., fol. 189r).

Alonso de la Paz: Natural de Añover, fue admitido el 24 de abril de 1589 (ib., fol. 190r).

Cristóbal Cordones: Fue admitido el 28 de abril de 1589 (ib., fol. 190v).

Gabriel de Huelves: El 5 de julio de 1589 quedó admitido como clerizón (ib., fol. 207v).

Juan García: Natural de Casamuros, fue admitido el 17 de noviembre de 1589 (ib., fol. 243v).

Diego Díaz: Natural de Añover, fue admitido el 17 de noviembre de 1589 (ib.).

Mateo Sánchez: Natural de San Martín de Valdeiglesias, fue admitido el 11 de diciembre de 1589 (ib., fol. 247v).

Hernando de Sepúlveda y Esteban Primo: Fueron admitidos el 20 de noviembre de 1589 (ib., fol. 251r).

Melchor de Guzmán: Fue admitido el 26 de enero de 1590 (ib., tomo 20, fols. $6 \mathrm{v}-7 \mathrm{r}$ ).

Antonio Alonso: Natural de Tembleque, se realizó su admisión el 3 de marzo de 1590 (ib., fol. 17r).

Juan de Torralba: Admitido el 20 de junio de 1590, era natural de Dosbarrios (ib., fol. 61r).

Alonso López: Natural de la Puebla de Montalbán, fue admitido el 3 de julio de 1590 (ib., fol. 63v).

Francisco de Oliva: Fue admitido el 6 de octubre de 1590 (ib., fol. 81v).

Esteban López: Natural de la Torre de Esteban Ambrán, fue admitido el 4 de abril de 1591 (ib., fol. 128r).

Juan Muñoz: Admitido el 23 de septiembre de 1591, era natural de Lillo (ib., fol. 175r).

Gonzalo Rubio: Fue admitido el 24 de septiembre de 1591 (ib.).

Francisco Hernández: Admitido el 29 de noviembre de 1591 (ib., fol. 190v)

Diego Sánchez: Fue admitido el 2 de diciembre de 1591 (ib., fol. 191r).

Pedro Gómez de Rojas: Natural de Sonseca, fue admitido el 11 de diciembre de 1591 (ib., fol. 192r).

Francisco Rodero: Natural de Miguel Turra, fue admitido el 17 de junio de 1592 (ib., fol. 245v).

Pedro de Rama: Admitido el 14 de octubre de 1592 (ib., fol. 271r). 
Francisco de Moraleda: Fue admitido el 26 de octubre de 1592 (ib., fol. 274r).

Pedro Hernández: Natural de Borox, fue admitido el 25 de junio de 1593 (ib., tomo 21, fol. 49v).

Pedro Hernández: Natural de Leganés, fue admitido el 10 de septiembre de 1593 (ib., fol. 69r).

Antonio Muñoz: Admitido el 13 de septiembre de 1593, era natural de Lillo (ib., fol. 70r).

Francisco Gómez: Natural de Sonseca, fue admitido el 29 de enero de 1594 (ib., fol. 112v).

Tomás Moraleja: Natural de Valdemoro, fue admitido el 1 de febrero de 1594 (ib., fol. 113r).

Juan Zorrilla de la Concha: Fue admitido el 29 de marzo de 1594 (ib., fol. 126v).

Aparicio Ruiz: Natural de Orche, fue admitido el 13 de julio de 1594 (ib., fol. 146r).

Miguel López: Fue admitido el 15 de octubre de 1594. Era natural de Vianos (ib., fol. 166v).

\section{REFITOLEROS:}

Licenciado Alonso Méndez de Robles: Vecino de Yepes, recibió el nombramiento el 12 de diciembre de 1577, para comenzar a ejercer el oficio el 1 de enero de 1578. Se le señaló un salario de seiscientos ducados cada año y cien escudos de gratificación por el trabajo de tomar las cuentas a los solicitadores (ib., tomo 16, fol. 148r).

Gonzalo Patiño: Su nombramiento fue realizado el 16 de octubre de 1581 (ib., tomo 17 , fol. 68 r).

Juan de Molina: El 30 de abril de 1588, el cabildo votó que permaneciese un año más ostentando este oficio, obteniendo nombramiento el 7 de enero de 1589 (ib., tomo 19, fols. 106r-107r, 156v-157r).

SACRISTANES GENERALES:

Alonso Caballero: Racionero, fue proveído en dicho cargo el 12 de junio de 1578 en lugar de Cristóbal de Berrio (ib., tomo 16, fol. 206v).

\section{ARCEDIANOS:}

Además de los ya consignados como canónigos aparecen: 
Fernando Enríquez: El 10 de septiembre de 1578, recibió nombramiento como arcediano de Madrid (ib., tomo 16, fols. 233r-234v).

Pedro de Deza junior: El 9 de septiembre de 1579, hizo presentación al cabildo de la provisión pontificia como arcediano de Calatrava (ib., fol. 306r).

Gabriel Suárez de Toledo: El 18 de abril de 1587, presentó al cabildo la bula y letras apostólicas por las que era proveído como arcediano de Madrid, cargo vacante por la resignación hecha en manos del pontífice por Fernando Enríquez (ib., tomo 19, fols, 24r-25r).

Gaspar de Quiroga: Capiscol y canónigo, el 15 de febrero de 1592, presentó al cabildo la provisión y colación hecha por Quiroga, por la que le proveía en el arcedianato de Talavera, vacante por la muerte del Cardenal Juan de Mendoza (ib., tomo 20, fols. 212r-v).

Rodrigo de Castro: Clérigo de la diócesis de Palencia, el 17 de mayo de 1593, notificó al capítulo la provisión y colación realizada por el arzobispo, por la que era proveído en el arcedianato de Alcaraz, vacante por el fallecimiento de Alonso del Águila. Tomó posesión el 14 de abril de 1594 (ib., tomo 21, fols. 38r-v, 93r, 127v-128r, 129v).

\section{ARCIPRESTES:}

Pedro de Tapia: Opositor la canonjía y prebenda doctoral obtenida por el doctor Navarro, fue proveído en el arciprestazgo de Santa Olalla el 22 de marzo de 1583 (ib., tomo 17, fol. 181r).

\section{CONSEJO DE LA DIGNIDAD}

Licenciado Martínez: En abril de 1578, tuvo una señalada actuación como visitador de las capillas (ib., tomo 16, fol. 190v).

Pedro de Pantoja: Era notario de la Audiencia arzobispal (ib., fols. 234r-v).

Doctor Juan de Obregón: Vicario general del arzobispado y de la ciudad de Toledo, en diciembre de 1579, fue nombrado canónigo por provisión arzobispal.

Licdo. Alonso Serrano: Promovido a una ración en noviembre de 1579, hizo dejación de la misma en agosto de 1581, tomando posesión en su lugar Jerónimo Serrano.

Francisco de Pantoja: Desempeñaba el oficio de secretario.

Licenciado Virviesca: En marzo de 1581, pasó a ocupar una canonjía doctoral vaca por el fallecimiento de Diego López de Quemada.

\section{Antonio Morejón.}

Francisco de Escobar: Era notario de la Audiencia arzobispal. 
Andrés Fernández: Vicario general del arzobispado, en marzo de 1584, fue promovido a una canonjía por provisión arzobispal.

Licenciado Bautista Vélez (Manuel GUTIÉRREZ GARCÍA-BRAZALES, «El Consejo de Gobernación del Arzobispado de Toledo». Anales toledanos 16 (1983), p, 107).

Pedro de Carvajal (Ib.) 